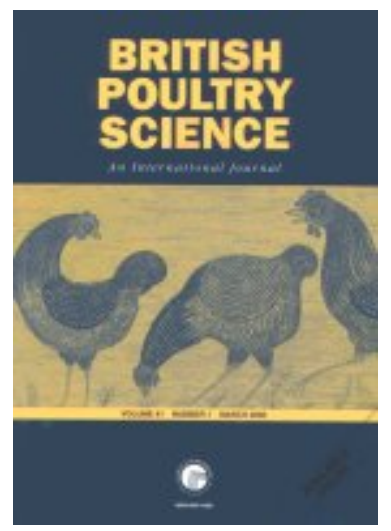

\title{
Lysolecithin, but not lecithin, improves nutrient digestibility and growth rates in young broilers
}

\begin{tabular}{|r|l|}
\hline Journal: & British Poultry Science \\
\hline Manuscript ID & CBPS-2019-438.R2 \\
\hline Manuscript Type: & Original Manuscript \\
\hline Author: & $13-J a n-2020$ \\
\hline Complete List of Authors: & $\begin{array}{l}\text { Wealleans, Alexandra; Kemin Europa NV } \\
\text { Buyse, Johan; KU Leuven, o Laboratory of Livestock Physiology, Division } \\
\text { of Animal and Human Health; KU Leuven, Leuven Food Science and } \\
\text { Nutrition Research Centre (LFoRCe) } \\
\text { Scholey, Dawn; Nottingham Trent University, School of Animal, Rural } \\
\text { and Environmental Science } \\
\text { Van Campenhout, Leen; KU Leuven, Department of Microbial and } \\
\text { Molecular Systems (M2S); KU Leuven, Leuven Food Science and } \\
\text { Nutrition Research Centre (LFoRCe) } \\
\text { Burton, Emily; Nottingham Trent University, Animal, Rural and } \\
\text { Environmental Sciences } \\
\text { DiBenedetto, Mauro; Kemin Europa NV } \\
\text { Pritchard, Steven; Premier Nutrition } \\
\text { Nuyens, Filip; Kemin Europa NV } \\
\text { Jansen, Matias; Kemin Europa NV }\end{array}$ \\
\hline \multirow{2}{*}{ Keywords: } & $\begin{array}{l}\text { Broilers, Fats and fatty acids, Lecithin, Lysolecithin, Performance, } \\
\text { Digestibility }\end{array}$ \\
\hline
\end{tabular}

\section{SCHOLARONE Manuscripts}



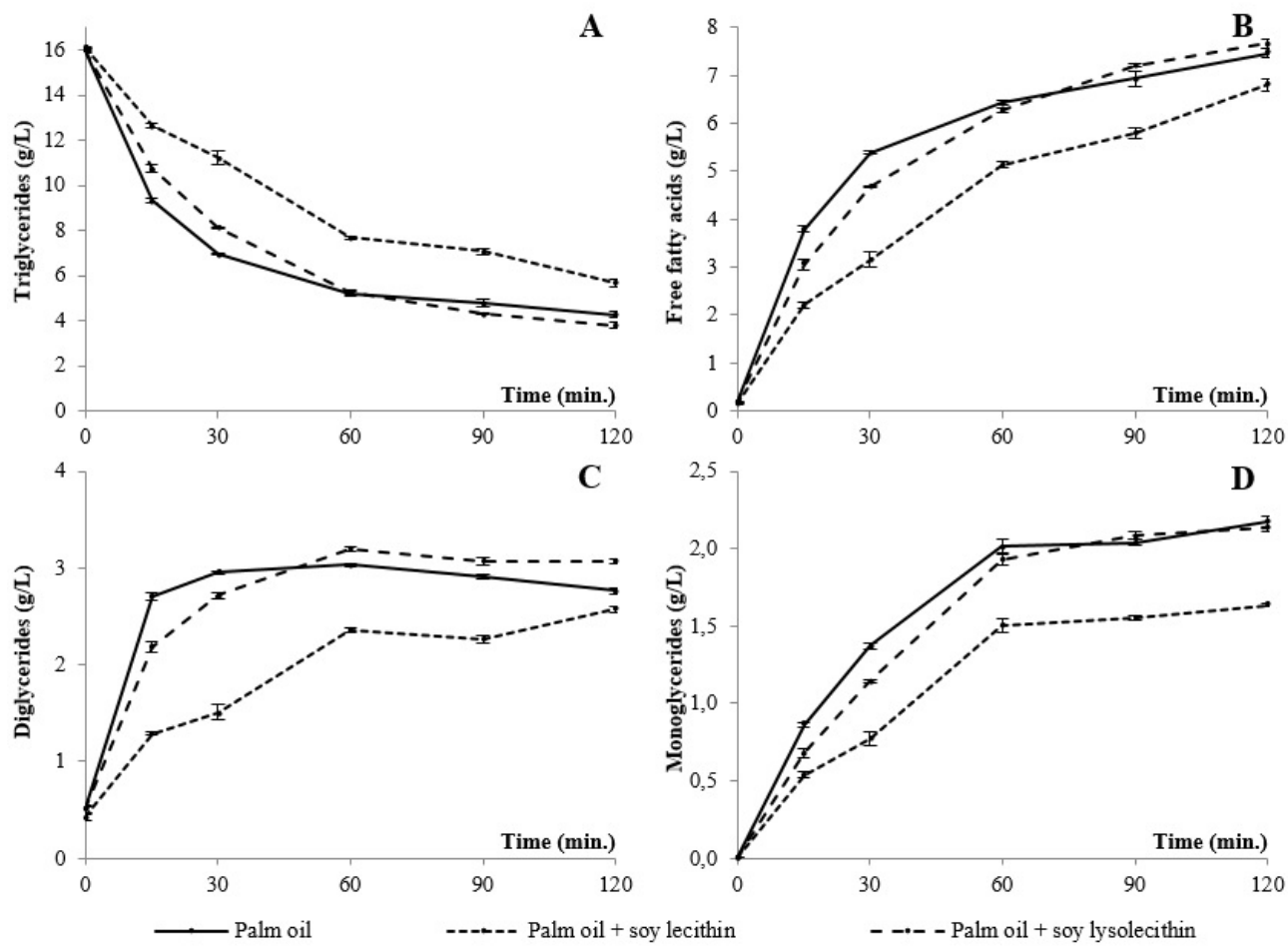

Figure 1. Hydrolysis of (A) triglycerides and accumulation of (B) free fatty acids, (C) diglycerides and (D) monoglycerides during the in vitro hydrolysis of palm oil (solid line), palm oil with soybean lecithin (dotted line) and palm oil with soybean lysolecithin (dashed line). The experimental treatments were carried out in triplicate. The mean concentrations of the lipids $(\mathrm{mg} / \mathrm{ml})$ are given over time $(\mathrm{min})$, with error bars indicating the standard error values. (Experiment 1$)$.

$179 \times 134 \mathrm{~mm}(120 \times 120 \mathrm{DPI})$ 


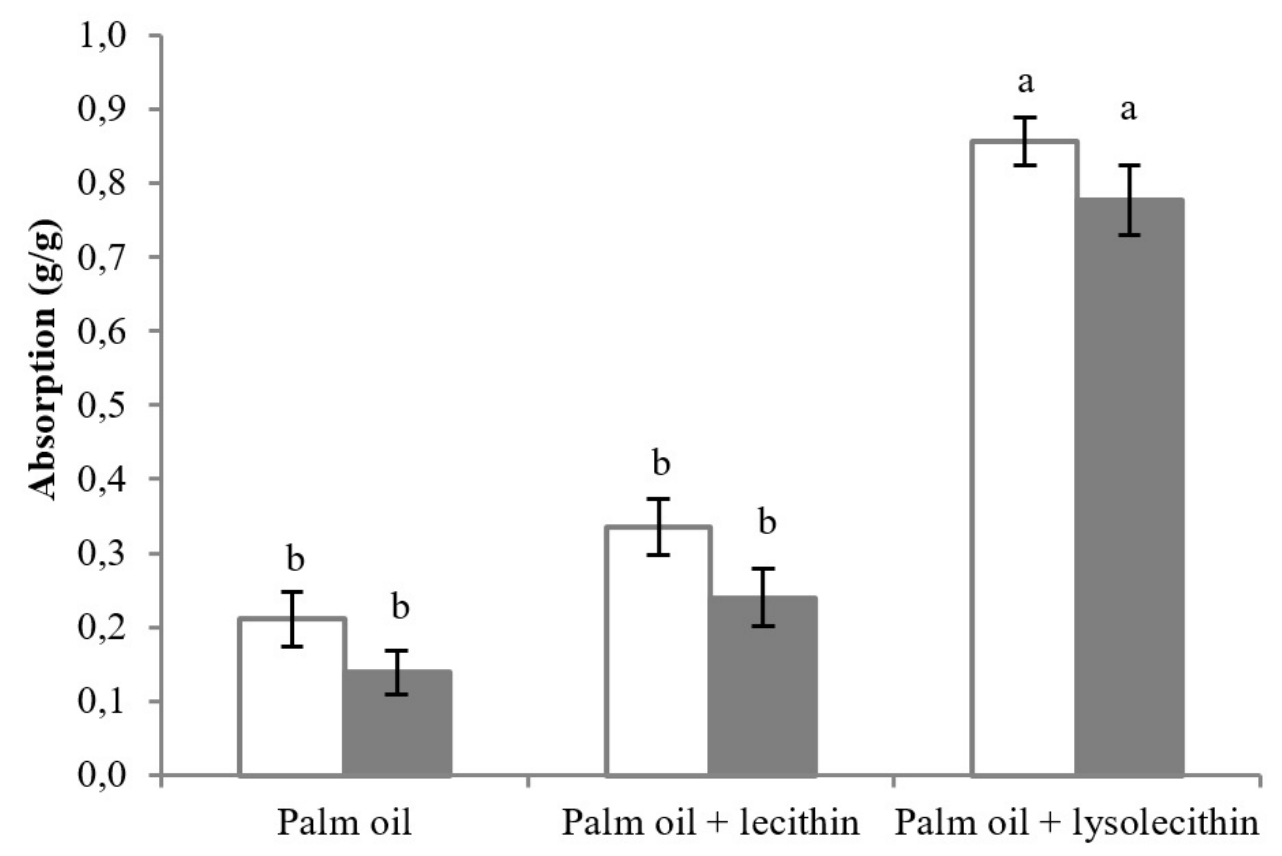

Figure 2. Absorption of monoglycerides (white bars) and free fatty acids (grey bars) generated during in vitro hydrolysis of palm oil, palm oil with soybean lecithin and palm oil with soybean lysolecithin by differentiated Caco-2 monolayers and expressed as percentage of applied monoglycerides end free fatty acids. Data are means of three or more observations per treatment, with error bars indicating the standard error values. (Experiment 1).

$201 \times 134 \mathrm{~mm}(120 \times 120 \mathrm{DPI})$ 
1 Supplemental Information Table 1. Fatty acid composition $(\mathrm{g} / \mathrm{kg})$ in palm oil and the ether

2 extract of the experimental starter diet (0-8 days of age) formulated with palm oil

\begin{tabular}{lrr}
\hline \hline Fatty acid & Palm oil & Diet $^{\mathrm{b}}$ \\
\hline C14:0 & 10.1 & 4.7 \\
C16:0 & 429.0 & 306.0 \\
C18:0 & 45.7 & 37.2 \\
C18:1 $(\omega-9)$ & 401.6 & 339.3 \\
C18:2 $(\omega-6)$ & 102.1 & 289.4 \\
C18:3 $(\omega-3)$ & 3.8 & 11.3 \\
Total unsaturated fatty acids & 507.5 & 643.8 \\
Total saturated fatty acids & 492.4 & 356.2 \\
Ratio unsaturated/saturated & 1.03 & 1.81 \\
\hline
\end{tabular}

$3 \quad{ }^{\text {a }}$ Fatty acids present at levels below $5 \mathrm{~g} / \mathrm{kg}$ in all samples are not listed.

$4 \quad \mathrm{~b}$ Values represent the mean of the three experimental diets with standard error of the means of

$5 \quad 0.1,0.1,0.4,2.3,1.6$ and $0.2 \mathrm{~g} / \mathrm{kg}$ for $\mathrm{C} 14: 0, \mathrm{C} 16: 0, \mathrm{C} 18: 0, \mathrm{C} 18: 1, \mathrm{C} 18: 2$ and $\mathrm{C} 18: 3$,

6 respectively.

7

8 Supplemental Information Table 2. Phospho- and lysophospholipid contents ${ }^{1}(\mathrm{~g} / \mathrm{kg})$ of

9 soybean lecithin and lysolecithin

\begin{tabular}{lcc}
\hline \hline (Lyso)phospholipid & Soybean lecithin & Soybean lysolecithin \\
\hline Phosphatidylcholine & 125.3 & 90.4 \\
Lysophosphatidylcholine & 7.8 & 39.2 \\
Phosphatidylinositol & 88.0 & 81.9 \\
Lysophosphatidylinositol & $\mathrm{ND}$ & 13.0 \\
Phosphatidylethanolamine & 97.2 & 33.6 \\
Lysophosphatidylethanolamine & 3.3 & 40.4 \\
Phosphatidic acid & 72.2 & 13.8 \\
Lysophosphatidic acid & 3.0 & 26.2 \\
Total phospholipids & 382.7 & 219.7 \\
Total lysophospholipids & 14.1 & 118.8 \\
\hline Contents of non-phospholipid compounds such as triglycerides, glycolipids, water and \\
\end{tabular}

12 
13 Supplemental Information Table 3. Levels of moisture, impurities and unsaponifiables, and

14 free fatty acids, U:S ratio, and predicted AME values for broilers $<21$ days in commercial oil

15 samples used to make experimental diets (Experiment 3)

\begin{tabular}{lccccc}
\hline \hline Oil Type & MIU, \% & FFA, \% & U:S ratio & $\begin{array}{c}\text { AME, } \\
\text { MJ/kg, }<21 \\
\text { days }\end{array}$ & $\begin{array}{c}\text { AME, } \\
\text { MJ/kg, }>21 \\
\text { days }\end{array}$ \\
\hline Lecithin & 3.70 & 24.8 & 3.7 & 32.30 & 34.31 \\
Lecithin & 3.60 & 24.6 & 4.1 & 32.72 & 34.56 \\
Lecithin & 3.50 & 18.7 & 3.7 & 32.89 & 34.73 \\
Soybean & 0.70 & 1.9 & 4.8 & 36.57 & 37.40 \\
Soybean & --1 & 1.9 & 4.7 & 36.57 & 37.66 \\
\hline
\end{tabular}

$16{ }^{1}$ Below limit of detection 
1 Lysolecithin, but not lecithin, improves nutrient digestibility and growth rates in young 2 broilers

AL Wealleans ${ }^{\dagger 1}$, J Buyse $^{\# \ddagger}$, D Scholey* ${ }^{*}$ L van Campenhout ${ }^{\ddagger}$, E Burton*, M Di Benedetto ${ }^{\dagger}, \mathrm{S}$ Pritchard $^{\#}$, F Nuyens ${ }^{\dagger}$, and M Jansen ${ }^{\dagger \#}$

6

$7 \quad$ Kemin Europa NV, Herentals, Belgium

8 \# Division Animal and Human Health Engineering, Department of Biosystems, KU Leuven, 9 Geel, Belgium

$10 \ddagger$ Leuven Food Science and Nutrition Research Center (LFoRCe), Leuven, Belgium

$11 *$ Nottingham Trent University, Southwell, United Kingdom

$12 \S$ Lab4Food, Cluster for Bioengineering Technology (CBeT), Department of Microbial and

13 Molecular Systems (M2S), KU Leuven, Geel, Belgium

14 \# Premier Nutrition, Rugeley, United Kingdom

${ }^{1}$ Corresponding author:

Alexandra L Wealleans

Kemin Animal Nutrition and Health

Toekomstlaan 42, 2200 Herentals

Belgium

21

Email:

alexandra.wealleans@kemin.com

22

Telephone:

$+447758134879$ 


\section{ABSTRACT}

Young broilers have an underdeveloped ability for lipid digestion. The potential of lecithin and lysolecithin to improve lipid digestion and growth performance was investigated in 3 experiments: an in vitro model that mimics the intestinal conditions of the chick, a digestibility trial with chicks ( 5 to 7 days of age), and a performance trial until 21 days of age. In Experiment 1, palm oil (PO), palm oil with lecithin $(\mathrm{PO}+\mathrm{L})$, and palm oil with lysolecithin (PO+LY) were subjected to in vitro hydrolysis and applied to Caco-2 monolayers to assess lipid absorption. The in vitro hydrolysis rate of triglycerides was higher in $\mathrm{PO}+\mathrm{LY}(\mathrm{k}=11.76 \times 10-3 \mathrm{~min}-1)$ than in either $\mathrm{PO}(\mathrm{k}=9.73 \times 103 \mathrm{~min} 1)$ or $\mathrm{PO}+\mathrm{L}(\mathrm{k}=8.41 \times 103 \mathrm{~min} 1)$, and the absorption of monoglycerides and free fatty acids was highest $(\mathrm{P}<0.01)$ for $\mathrm{PO}+\mathrm{LY}$. In Experiment 2, 90 broilers were assigned to three dietary treatments: a basal diet with $4 \%$ palm oil, and the basal diet supplemented with either $250 \mathrm{ppm}$ lecithin or lysolecithin. ATTD of crude fat was higher in broilers supplemented with lysolecithin, but was lower in broilers supplemented with lecithin. DM digestibility and AMEn in birds supplemented with lysolecithin were significantly higher (3.03\% and $0.47 \mathrm{MJ} / \mathrm{kg}$, respectively). In Experiment 3, 480 broilers were randomly allocated to four dietary treatments: basal diet with soybean oil (2\%), basal diet with lecithin (2\%), soybean oil diet with $250 \mathrm{ppm}$ lysolecithin, or lecithin oil diet with $250 \mathrm{ppm}$ lysolecithin. Lecithin diets significantly reduced weight at day 10 and 21 compared with soybean oil. However, the addition of lysolecithin to lecithin-containing diets significantly improved bird performance. The results of these studies show that, in contrast to lecithin, lysolecithin is able to significantly improve the digestibility and energy values of feed in young broilers.

KEYWORDS: broiler; digestibility; fat; lecithin; lysolecithin; performance 


\section{INTRODUCTION}

After hatch, lipid digestion in young birds is physiologically limited, and is a target for improvement and support. Roy et al. (2010) have ascribed the inefficient digestion and absorption of lipids by young chickens to a combination of a low duodenal secretion of lipase, a low level of lipase activity and a low rate of bile salt synthesis. Kroghdahl (1985) and Maiorka et al. (2004) showed, however, that lipase concentration and activity in young chickens (7 days of age) are modulated according to the inclusion level of fats in the diet. Moreover, in a study of Meng et al. (2004), lipase addition at $0.2 \mathrm{~g} / \mathrm{kg}$ did not affect the apparent fat digestibility in broilers of one to 14 days of age. Therefore, the inability to utilize fats has been attributed to low bile salt concentrations in the intestines, rather than to deficiencies in lipase secretion or activity (Maiorka et al., 2004; Maisonnier et al., 2003). Although dietary supplementation of bile salt has been shown to improve lipid utilization in chickens (Krogdahl, 1985; Polin et al 1980), supplementation is generally not applied on a commercial scale due to economic drawbacks (Roy et al., 2010).

One strategy for improvement of fat digestion is the dietary application of molecules with proven ability to improve lipid digestion, for example lecithin and its derivative lysolecithin. Huang et al. (2007) showed that in diets supplemented with $2 \%$ of soybean oil, replacement of $25 \%$ of the soybean oil with soybean lecithin $(0.5 \%$ lecithin in the diet) improved crude fat digestion and performance in broilers. On the other hand, complete replacement of the soybean oil with lecithin ( $2 \%$ lecithin in the diet) resulted in adverse effects. Moreover, in a study of Blanch et al. (1996) the AME of a basal diet with tallow as the main fat source was not improved by the addition of $0.2 \%$ soybean lecithin.

Lysolecithins are produced by phospholipase to cleave one hydrophobic fatty acid from phospholipids (Joshi et al., 2006). This changes the stereochemical structure of the phospholipids in the lecithin into lysophospholipids. The resulting mixture, lysolecithin, has 
an increased hydrophilic-lipophilic balance (Van Nieuwenhuyzen and Tomás, 2008) and lowere critical micelle concentration ( 0.02 to $0.2 \mathrm{mM} / \mathrm{L})$. Both phospho- and lysophospholipids consist of a hydrophilic head group (phosphatidyl substituent) and a hydrophobic tail (fatty acid chains). But, due to the removal of one fatty acid, lysophospholipids are more hydrophilic and thus have better oil-in-water emulsifying properties than phospholipids (Joshi et al., 2006; Liu and Ma, 2011). In the animal, the pancreas secretes native phospholipase (EC 3.1.1.4) to convert the phospholipids secreted by the gall bladder into lysophospholipids (Karray et al., 2011). These lysophospholipids were shown to play an important role in mixed micelle formation (Lo and Tso, 2009). Therefore, it is hypothesized that lysolecithin possess a greater ability to improve the digestion of fats and oils than lecithin. Inclusion of $3.2 \%$ of rice bran lysolecithin in a broiler feed formulated with rice bran oil increased the crude fat digestibility (Raju et al., 2011). Additionally, Zhang et al. (2011) observed an increased fatty acid digestibility in broilers using $0.125 \%$ of soybean lysolecithin on soybean oil, tallow and poultry fat. These improvements in digestibility consistently lead to improved growth performance and efficiency in growing broilers (Wealleans et al., 2019), as well as in other species (Wang et al., 2019; Zhao et al., 2017; Papadopoulos et al., 2014).

The limited comparative studies available on lecithin and lysolecithin application in broiler diets have, however, all been performed with birds of 14 days of age or older. Therefore, the potential of both lecithin and lysolecithin from soybean to improve lipid digestion was investigated in 3 experiments: an in vitro model, a digestibility trial with young broilers (5 to 7 days of age), and a performance trial until 21 days of age.

\section{METHODS AND MATERIALS}

Experiment 1: In Vitro Fat Absorption 
100 Crude palm oil (single batch) was sourced from a commercial feed mill in Belgium. 101 The FA composition of the palm oil was analysed (ISO, 2002, 17764). Soybean lecithin and 102 soybean lysolecithin were sourced from Kemin Europa NV (Herentals, Belgium). Lecithin and 103 lysolecithin were analysed for their phospho- and lysophospholipid content by phosphorus-31 104 nuclear magnetic resonance spectroscopy $\left({ }^{31} \mathrm{P}-\mathrm{NMR}\right.$, Spectral Service AG, Cologne, 105 Germany).

106 The lipid hydrolysis model previously employed by Jansen et al. (2015) was slightly 107 modified. Briefly, $1.00 \mathrm{~g}$ of lecithin or lysolecithin were first dispersed into $49.00 \mathrm{~g}$ of palm 108 oil. Fasted state simulated intestinal fluid (FaSSIF) was prepared by adding $2.24 \mathrm{~g}$ of FaSSIF 109 powder (Biorelevant.com Ltd, Croydon, United Kingdom) to $1 \mathrm{~L}$ of phosphate buffer (35 mM, $110 \mathrm{pH}$ 6.5) containing $106 \mathrm{mM} \mathrm{NaCl}$. According to the manufacturer, the FaSSIF contained $3 \mathrm{mM}$ 111 bile salt (sodium taurocholate). Aliquots of $0.25 \mathrm{~g}$ of each of the respective fat treatments and $11214.75 \mathrm{ml}$ of FaSSIF were added into $50 \mathrm{ml}$ centrifuge tubes. The content of each tube was 113 mixed for 30 seconds with a high shear mixer $(24000 \mathrm{rpm}$; IKA ultra-turrax T18, Staufen, 114 Germany). Next, $24 \mathrm{mg}$ of pancreatin (P7545, Sigma Aldrich) was added to each tube and they were incubated for two hours at $40{ }^{\circ} \mathrm{C}$ while shaking $(250 \mathrm{rpm})$. The final contents in the digests in triplicate. Samples of the digests were submerged in liquid nitrogen and stored at $-180{ }^{\circ} \mathrm{C}$ till absorption experiments started.

Human colonic adenocarcinoma cells (Caco-2) were obtained from the European

123 Collection of Cell Cultures (Public Health England, Porton Down, Salisbury, UK). Caco-2 cell work stock was used between passages 54 and 60. Cells were cultured in Dulbecco's modified 
eagle medium supplemented with $100 \mathrm{ml} / \mathrm{L}$ heat-inactivated fetal bovine serum (Hyclone, Thermo scientific, Leuven, Belgium), $10 \mathrm{ml} / \mathrm{L}$ non-essential amino acids, $100 \mathrm{U} / \mathrm{ml}$ of penicillin and $100 \mathrm{U} / \mathrm{ml}$ of streptomycin. The cells were maintained at $37{ }^{\circ} \mathrm{C}$ in a humidified atmosphere of $5 \% \mathrm{CO}_{2}$ and routinely passaged. Unless stated otherwise, the cell culture media and supplements were provided by Westburg (Leusden, The Netherlands).

Caco-2 cells were seeded on collagen-coated Transwell-COL inserts $\left(1.12 \mathrm{~cm}^{2}\right.$, pore size $0.4 \mu \mathrm{m}$, Corning Costar Corporation, Cambridge, MA) in 24-well plates at a density of 2 x $10^{5}$ cells per insert and incubated for 21 days to allow the cells to differentiate. During incubation the medium (apical and basal) was changed three times a week and the transepithelial electrical resistance was monitored (Millicell-ERS, Millipore, Overijse, Belgium). Next, the different digests obtained with the lipid hydrolysis model were diluted 25-fold in FaSSIF and applied at the apical side of the monolayer. Simultaneously, Hank's balanced salt solution was applied at the basal side of the monolayer. The digest concentration and the differentiation protocol were optimized during the development of the model. Similar to Vors et al. (2012), a 25-fold dilution of the digests was selected to avoid toxicity while still presenting sufficient monoglycerides (MG) and free fatty acids (FFA) to the monolayers. At the start and after 60 minutes of incubation, a sample of the apical fluid was taken and diluted twofold in tetrahydrofuran. Each absorption experiment performed in at least three replicates. In each sample obtained during the in vitro lipid digestion, the degree of lipid hydrolysis was analyzed by HPLC. The lipids were separated into triglycerides (TG), diglycerides (DG), MG and FFA by a gel permeation column (PL 1110-6520, $5 \mu \mathrm{m}$ 100A 300 x $7.5 \mathrm{~mm}$, Agilent Technologies, Diegem, Belgium) and detected by an Evaporative Light Scattering Detector (ELSD 85, VWR International). tetrahydrofuran was used as the mobile phase at a flow rate of $0.5 \mathrm{ml} / \mathrm{min}$. Likewise, samples obtained with the lipid absorption model were analysed for their MG and FFA content. 
150 The hydrolysis of palm oil at each sample time was calculated and the apparent rate 151 constant for TG hydrolysis and FFA, MG and DG release were determined as described by 152 Jansen et al. (2015). The absorption of MG (g/g) in each well was calculated as follows: MG absorption $=\frac{M G_{0}-M G_{60}}{M G_{0}}$

154 where ${ }^{M G_{0}}$ and $M G_{60}$ are the respective MG contents $(\mathrm{g} / \mathrm{L})$ before and after 60 minutes of 155 incubation. Correspondingly, FFA absorption (g/g) was calculated from the respective FFA 156 contents. done with STATGRAPHICS Centurion XVI software (Statpoint Technologies Inc., Warrenton, VA), and means were separated by the least significant differences procedure. All

Experiment 2: Digestibility Trial

A broiler digestibility trial was performed at the experimental research facility of the

Laboratory of Livestock Physiology (Leuven, Belgium). The experiments were conducted in strict accordance with the European Communities Council Directive (2003/65/EC) and were approved by the Ethical Commission for Experimental Use of Animals of the KU Leuven (P213/2015). A total of 90 one-day-old male Ross 308 chickens were obtained from Belgabroed NV (Merksplas, Belgium) and assigned randomly at day zero, in groups of ten birds, to three dietary treatments: a basal diet without lecithin and lysolecithin, the basal diet

172 supplemented with $250 \mathrm{ppm}$ lecithin and the basal diet supplemented with $250 \mathrm{ppm}$ 
173 lysolecithin. Lecithin and lysolecithin were applied to diets at the same rate in order to allow 174 direct comparison of the effects of phospholipids and lysophospholipids.

175 To prepare the experimental diet (Table 2), first all raw materials were milled together 176 to obtain homogeneous batches. Next, the feed was divided into three batches and successively 177 mixed in a small mixer with different premixes in order to produce the three experimental diets. 178 Titanium dioxide (E171 titanium dioxide, IMCD Benelux N.V., Mechelen, Belgium) was 179 added to all diets as an indigestible marker at an inclusion rate of $3 \mathrm{~g} / \mathrm{kg}$. All diets were fed as 180 mash diets and also contained a commercial enzyme blend (KEMZYME Plus Concentrate Dry 18150 ppm, Kemin Europa NV) and phytase (RONOZYME P-(CT) 100 ppm, DSM Nutritional 182 products, Deinze, Belgium).

Birds were housed in nine digestibility cages (three replicates per treatment), consisting of a wire bottom with a plastic tray for excreta collection, two feed troughs and a drinking cup. The facility was kept under conventional EU conditions for lighting, heating and ventilation. provided ad libitum. During the collection period, total excreta were collected, and pooled and homogeneous samples of the mixed wet excreta were freeze-dried and stored until analysis.

The titanium dioxide was determined using the method of Short et al. (1996) with modifications according to Myers et al. (2004). Samples of the feed and freeze-dried excreta 192 were analyzed in the accredited laboratory of the Institute for Agricultural and Fisheries 193 Research (ILVO, Merelbeke, Belgium) for dry matter (DM), gross energy (GE), crude protein 194 and crude fat according to EC (1971), ISO (1998, 9831), ISO $(2005,5983-2, \mathrm{~N} \times 6.25)$ and 195 ISO (1999, 6492), respectively. Additionally, the FA distribution of the ether extracts of the 196 diet and excreta samples were determined (ISO, 2002, 17764). 
197 The coefficient of total tract apparent digestibility (CTTAD) of DM, crude protein and 198 crude fat were determined by the use of the concentrations of titanium dioxide in the excreta 199 and in the feed and calculated as described by Jansen et al. (2015). For the titanium dioxide in 200 the feed a single value, averaged over the diets, was used for all calculations. Average diet 201 titanium recovery was within acceptable limits for all diets. The coefficients of total tract 202 apparent digestibility of individual fatty acids (CTTADF) were calculated as follows:

$C T T A D F=\frac{\left[F A_{\text {diet }}-\left(F A_{\text {excreta }} \times(1-C T T A D \text { of crude fat })\right)\right]}{\left[F A_{\text {diet }}\right]}$

204 where $F A$ diet and FAexcreta are the respective FA contents $(\mathrm{g} / \mathrm{kg})$ analyzed in the ether extracts 205 of the diet and excreta samples. The AME contents of the experimental diets were calculated 206 from their respective titanium dioxide ratios and corresponding GE contents, as described by 207 Jansen et al. (2015).

208 The values for CTTAD of DM and crude fat, CTTADF, N-retention and AMEn were 209 analysed as a one factorial arrangement and subjected to ANOVA with STATGRAPHICS 210 Centurion XVI software (Statpoint Technologies Inc.). Repeated measures techniques were not 211 used. Means were separated by the least significant differences procedure. All statements of 212 significance were based on a P-value equal to or less than 0.05 .

Experiment 3: Performance Trial

All experimental procedures were conducted in strict accordance with the European 216 Communities Council Directive (2003/65/EC) and were approved by the Ethics Committee of 217 Nottingham Trent University.

218 Birds were sourced from PD Hook Cote hatchery, Oxford. Birds were feather sexed on 219 day of hatch and collected by Nottingham Trent University (NTU) personnel to reduce travel 220 stress. A total of 480-day-old male Ross 308 chicks were individually weighed before random 
221 allocation to $80 * 80 \mathrm{~cm}$ mesh sided pens bedded on clean wood shavings. Unhealthy or

222

223

224

225

226

227

228

229

230

231

232

233

234

235

236

237

238

239

240

241

242

243

244

245 unusually sized chicks were discarded from the trial upon arrival. Birds were individually weighed and only birds between 33 and $46 \mathrm{~g}$ were placed.

Birds were allocated to four dietary treatments in a $2 \times 2$ factorial design. Treatments were: basal diet with soybean oil (2\%), basal diet with lecithin oil (2\%), basal diet with soybean oil with 250 ppm lysolecithin, or basal diet with lecithin oil with 250 ppm lysolecithin. Compared to Experiment 2, where dietary fat type and level were used to create challenging diets that could elucidate clearly the mode of action of lysolecithin, in Experiment 3 the basal diets were formulated to reflect relevant commercial compositions and to meet all nutrient requirements of the birds (Table 5). The lecithin-based oil used in this study is commercially available as Leciol (Adams and Green, East Yorkshire, UK). The lysolecithin was supplemented as LYSOFORTE ${ }^{\circledR}$ EXTEND (Kemin Animal Nutrition and Health, Belgium). Each treatment consisted of 12 pens, with 10 birds per pen. Diets were manufactured by Target Feeds (Whitchurch, UK) and supplied bagged as crumb for both starter and grower. Feed and water were available ad libitum, with care taken to ensure the birds ate and drank as soon as possible after placement.

The lighting regimen was maintained in accordance with commercial practice with 15 minutes of dusk at the start and end of each dark period. Temperature was set at $31^{\circ} \mathrm{C}$ on day 1 and reduced by approximately $1{ }^{\circ} \mathrm{C}$ per day until $21^{\circ} \mathrm{C}$ was reached.

Bird observations were used to monitor the environment and if the birds appeared uncomfortable, the temperature and/or ventilation was altered accordingly. Birds were observed twice daily during the trial and any observations related to health recorded in a trial diary. Any dead birds were weighed, and reasons recorded if culled. Birds were weighed by pen on arrival, on day 10 and at the end of the trial on day 21. Initially, individual weighed bags of feed were prepared containing precisely weighed feed quantities for each phase. Each 
246 pen of birds was fed from their designated bag for each phase. Extra feed was added to the bags

247 as required and the quantity recorded. Total feed eaten was calculated as the difference between

248 remaining feed in the bag and the amount weighed into the bag for each phase.

249 Energy conversion efficiency ( $\mathrm{ME} \mathrm{MJ} / \mathrm{kg}$ gain) was calculated according to the

250 following formula, as per Salah et al. (2004):

251

Calorie conversion $=\frac{\text { Total Feed Consumption } \times \text { Energy content of feed }}{\text { Sum weight of all birds at trial end }}$

252 Calorie conversion was calculated using the calculated ME contents on the feed, using both on 253 the literature energy value of the two fat sources, as claimed by the manufacturers, and with 254 the energy value as determined by the Wiseman equation (Wiseman et al., 1991).

Statistical analysis was carried out using SPSS v.24. After KS testing to confirm elucidate differences between diets/treatments.

RESULTS

Experiment 1: In Vitro Fat Absorption

In Experiment 1, the palm oil contained a high amount of saturated FA (492.4 g/kg), 264 especially palmitic acid $(429.0 \mathrm{~g} / \mathrm{kg})$, which was largely reflected in the FA in the ether extract 265 of the diet (Supplemental Information Table 1). The total lysophospholipid fraction was confirmed to be much higher for soybean lysolecithin than for soybean lecithin $(118.8 \mathrm{~g} / \mathrm{kg}$ lysolecithin vs 14.1 lecithin; Supplemental Information Table 2). The majority of 268 lysophospholipids in soybean lysolecithin were lysophosphatidylcholine (LPC) and 269 lysophosphatidyl-ethanolamine. 

hydrolysis of palm oil, palm oil with lecithin and palm oil with lysolecithin are shown in Figure 1. Over the whole incubation period of $120 \mathrm{~min}$, the amounts of TG hydrolysed and FFA, DG and MG accumulated in palm oil with lecithin are markedly lower than those of palm oil and palm oil with lysolecithin. During the first $60 \mathrm{~min}$ of incubation, the amounts of TG hydrolysed and FFA and MG accumulated were slightly higher in palm oil without lysolecithin or lecithin than in palm oil with lysolecithin. After $120 \mathrm{~min}$, however, the amounts of TG hydrolysed and FFA and DG accumulated was slightly higher in palm oil with lysolecithin than in palm oil without lysolecithin.

A comparison of the apparent first-order rate constants for TG hydrolysis and the accumulation of FFA, DG and MG for each treatment is presented in Table 1. Addition of lecithin or lysolecithin to the palm oil had significant $(\mathrm{P}<0.01)$ impact on the rates of TG hydrolysis and FFA, DG and MG release. TG were hydrolysed faster when lysolecithin was added to the palm oil $(\mathrm{k}=11.76 \times 10-3 \mathrm{~min}-1)$ compared to palm oil without (lyso)lecithin ( $\mathrm{k}$ $=9.73 \times 103 \mathrm{~min} 1)$. In contrast, TG were hydrolysed slower when lecithin was added $(\mathrm{k}=$ $8.41 \times 103 \mathrm{~min} 1$ ). Similarly, the release of monoglycerides was the fastest in palm oil with lysolecithin $(\mathrm{k}=3.07 \times 103 \mathrm{~min} 1)$ and the slowest in palm oil with lecithin $(\mathrm{k}=2.23 \times 103$ min 1). In contrast, DG release was the slowest in palm oil without lecithin or lysolecithin. There was no statistically significant difference observed in the rate of free fatty acid release between palm oil and palm oil with lecithin.

The absorption of MG and FFA generated during in vitro hydrolysis of palm oil, palm oil with lecithin and palm oil with lysolecithin is presented in Figure 2. The absorption of monoglycerides was significantly higher $(\mathrm{P}<0.01)$ for palm oil with lysolecithin $(85.6 \%)$ than

293 for palm oil (21.1\%) and palm oil with lecithin (35.5\%). The overall absorption of FFA was 294 slightly lower $(\mathrm{P}>0.1)$ than that of MG. Nevertheless, the absorption of FFA was significantly 
295 higher $(\mathrm{P}<0.01)$ for palm oil with lysolecithin $(77.8 \%)$ than for palm oil $(13.9 \%)$ and palm oil 296 with lecithin $(24.0 \%)$.

\section{Experiment 2: Digestibility Trial}

For Experiment 2, during the collection period, the observed feed intake values were

300 similar for all treatments with an average of $30.6 \mathrm{~g}$ per bird per day. Likewise, bodyweight gain

301 values were similar for all treatments with an average of $26.35 \mathrm{~g}$ per bird per day. Apparent

302 faecal digestibility values and AMEn are presented in Table 3.

There were significant differences $(\mathrm{P}<0.05)$ between the treatments on all parameters investigated. Compared to the basal diet, lysolecithin supplementation increased $(\mathrm{P}<0.01)$ the DM digestibility by $1.04 \%$, CF digestibility by $2.25 \%$ and AMEn by $0.47 \mathrm{MJ} / \mathrm{kg}$. On the other hand, supplementation of lecithin had no effect on dry matter digestibility or AMEn, but reduced $(\mathrm{P}<0.01)$ the crude fat digestibility by $3.2 \%$. When compared to the basal diet, Nretention was not significantly affected by lecithin or lysolecithin supplementation. However, the N-retention of the basal diet supplemented with lysolecithin $(27.75 \mathrm{~g} / \mathrm{kg} \mathrm{DM})$ was higher $(\mathrm{P}<0.05)$ than that of the basal diet supplemented with lecithin $(25.26 \mathrm{~g} / \mathrm{kg} \mathrm{DM})$. The fatty acid distribution in the ether extracts of the faeces is presented in Table 4. There was no difference $(\mathrm{P}>0.05)$ between any of the dietary treatments in the fatty acid distribution in the faeces, nor in the ratio of unsaturated over saturated fatty acids.

\section{Experiment 3: Performance Trial}

Table 6 shows the performance of the birds across the whole experimental period of

317 Experiment 3. During the starter phase, days 0-10, there were no significant differences in average daily gain, feed intake or FCR between the treatment groups. But, birds fed the diet with lecithin-based oil supplemented with lysolecithin were significantly heavier than those 
320 fed the diet with lecithin-based oil alone. During the grower phase there was a significant

321 difference in bird weight. Birds fed the diet with lecithin-based oil alone were significantly

322 lighter in weight when compared to the birds fed the diet with lecithin-based oil supplemented 323 with lysolecithin $(\mathrm{p}=0.047)$. Similarly, when the whole trial phase was evaluated there were 324 significant differences in average daily gain. Birds fed diets with lecithin-based oil alone gained 325 less on average daily $(\mathrm{p}=0.036)$ than the birds fed the diet with lecithin-based oil supplemented 326 with lysolecithin $(\mathrm{p}=0.036)$.

327 The energetic values of each oil determined through analysis of chemical composition 328 (Supplemental Information Table 3) demonstrated that, due to high levels of free fatty acids in 329 the oils and an altered unsaturated: saturated ratio (Wiseman et al., 1991), the lecithin oil had 330 a reduced predicted AME value for broilers $<21$ days compared to the soybean oil $(36.57 \mathrm{MJ} / \mathrm{kg}$ 331 soybean vs $32.64 \mathrm{MJ} / \mathrm{kg}$ lecithin). When calculating diet density based on the lipid analysis, 332 therefore, rather than assumed energetic equivalence between the two oil sources, the effective 333 energy conversion rate for soybean oil alone was $16.04 \mathrm{MJ} / \mathrm{kg} \mathrm{BWG}$, while the effective energy 334 conversion rate for lecithin oil alone was worse, at $16.78 \mathrm{MJ} / \mathrm{kg}$ BWG. With the addition of 335 lysolecithin, the energy conversion rate was improved across both fat sources $(15.58 \mathrm{MJ} / \mathrm{kg}$ 336 BWG soybean oil + lysolecithin; 16.23 MJ/kg BWG lecithin plus lysolecithin); the effective 337 efficiency of use of the lecithin oil was brought closer to that of unsupplemented soya oil.

\section{DISCUSSION}

340 The structural differences in the composition of lecithin and lysolecithin leads to 341 fundamentally diverse effects on both in vitro and in vivo lipid digestion. In Experiment 1, 342 compared to palm oil without lecithin or lysolecithin, in vitro the apparent rate constants for 343 triglyceride hydrolysis and monoglyceride release were significantly higher for palm oil 344 supplemented with lysolecithin and significantly lower for palm oil supplemented with 
345 soybean lecithin (Figures 1 and 2). Likewise, in Experiment 2, compared to the basal diet, the 346 crude fat digestibility was significantly higher in broilers supplemented with lysolecithin, while 347 it was significantly lower in broilers supplemented with lecithin. Though the limitations of this 348 initial study require further data to confirm these findings, Zhang et al. (2011) postulated that 349 while both lecithin and lysolecithin may act as an emulsifier within the first stages of lipid 350 digestion, for lipid hydrolysis to take place, the pancreatic colipase-lipase complex first must 351 adsorb onto the emulsion droplets (Reis et al., 2010). The adsorption and activity of lipase at 352 the oil-water interface, however, is affected by various surface-active compounds such as 353 phospholipids and lysophospholipids (Reis et al., 2010, 2009).

Possibly, the observed effect of lecithin on crude fat digestion in young broilers in 355 Experiment 2 could be explained by a study of Chu et al. (2010) who showed that colipase and 356 lipase adsorbed exclusively onto regions covered by phosphatidylcholine and bile salts and not 357 to regions covered with phosphatidylcholine solely. This would suggest that, although 358 phospholipids in lecithin may have aided the formation of smaller emulsion droplets, in the 359 conditions of the young broiler insufficient bile salts are present - especially with diets 360 containing high levels of palm oil where, due to the low amount of unsaturated fatty acids, 361 digestibility is more challenging than that of other, more unsaturated, vegetable oils such as 362 soybean oil (Tancharoenrat et al., 2013) - to facilitate the adsorption of the colipase-lipase 363 complex to the surface of the droplet. The combination of the challenging basal fat type (palm 364 oil) and level with the immature digestive system in young broilers led to a relatively low crude 365 fat digestibility in the basal diet (69.52\%) seen in Experiment 2; it is well known that relative 366 digestibility coefficients of fat are limited when fats and oils are presented at a high level 367 (Croom et al., 1999; Rampone, 1961), as the ability of the digestive system and liver for 368 lipolysis and absorption become rate limiting. However, in contrast to the phospholipids 369 contained in lecithin, it has been suggested that once in the small intestine, lysophospholipids 
370 tend to dissolve into mixed micelles and in this way leave the interface (Malaki-Nik et al., 201z으). Moreover, through their participation in the formation of mixed micelles, lysophospholipids may play an additional role by displacing monoglycerides and FFA from the interface allowing the lipid hydrolysis process to continue (Lairon, 200913). Recent studies have also demonstrated the effect of lysolecithin on the intestinal mucosa - Papadopoulos et al. (2018) reported significantly thinner mucosa in birds supplemented with lysolecithin than in unsupplemented birds, while Chen et al. (2019) reported elevated claudin-3 levels following lysolecithin supplementation, indicating better sealing of tight junctions (Milatz et al., 2010). Brautigan et al. (20162017) also showed increased collagen deposition and villus height following lysolecithin supplementation. Together, these results suggest that as lysolecithin becomes incorporated into the epithelial cell walls it also improves mucosal absorptive capacity in a way lecithin cannot.

Although in this proof of concept study lecithin had a negative effect on lipid hydrolysis, no adverse effect was observed on the absorption of generated monoglycerides and FFA by the differentiated Caco-2 monolayer (Figure 2). This also supports the argument that phospholipids likely reside at the interface of emulsion droplets and in this way do not participate in the absorption process at the enterocytes. In contrast, the absorption of monoglycerides and FFA was higher with digests from the palm oil supplemented with lysolecithin than with digests from palm oil and palm oil supplemented with lecithin. Similarly, in a study by Sugawara et al. (2001) the uptake of lipid-soluble carotenoids was greatly improved in Caco-2 cells exposed to micelles containing lysophosphatidylcholine in comparison to cells incubated with micelles containing phosphatidylcholine.

In addition to the improved CF digestibility, the DM digestibility and AMEn of basal diet supplemented with lysolecithin was also significantly higher than that of the basal diet and the basal diet supplemented with lecithin. This is in line with previous studies, which have 
395 shown improvements in CF and $\mathrm{N}$ digestibility following lysolecithin supplementation, though 396 the effect of fat source on response is still uncertain: Zaefarian et al. (2015) reported improved 397 AMEn values in supplemented soy oil diets, but little effect of lysolecithin on diets formulated 398 with tallow, while conversely, Jansen et al. (2015) reported improvement of the AMEn of diets 399 formulated with pig lard but not those formulated with soybean oil. Across 33 studies, 400 Wealleans et al. (2019) found little evidence that the magnitude of response to lysolecithin 401 supplementation was consistently altered by dietary fat type. In the present study, the N402 retention in the basal diet supplemented with lysolecithin was also significantly higher than 403 that in the basal diet supplemented with lecithin. Furthermore, the AMEn improvement of 0.47 $404 \mathrm{MJ} / \mathrm{kg}$ by lysolecithin supplementation can only be partially attributed to the $2.25 \%$ 405 improvement in CF digestibility.

406 Honda et al. (2009) found that fats incorporated in the feed matrix could cover other 407 nutrients, lowering their digestion. As a consequence of the improved CF digestibility, 408 lysolecithins could in this way enhance the digestion of other nutrients. Another possible 409 explanation for the large improvement in AMEn may be found at the enterocyte level. As 410 supported by the improved absorption of MG and FFA in the present study, lysolecithin may 411 enhance the uptake of multiple nutrients across the enterocyte membrane. Lysophospholipids 412 are known to alter membrane structure by inducing local curvatures of the bilayer (Lundbaek, 413 2006; Wendel, 2000; Maingret et al., 2000). Moreover, they can affect proteins embedded in 414 the membrane (Lundbaek, 2006; Maingret et al., 2000; Lundbaek and Andersen, 1994). In this 415 way lysophospholipids could enhance the uptake of nutrients across the membrane of the 416 microvilli in the intestinal epithelium; this is supported by the work of Brautigan et al. 417 (20162017), who reported increased villus height and collagen cross-linakges, driven by 418 upregulation of collagen-related genes, in the intestinal epithelium of broilers supplemented 419 with lysolecithin. 
420 These differential effects on fat hydrolysis and overall digestibility between lecithin 421 and lysolecithin are supported by the performance results of Experiment 3, although the basal 422 diet formulations were substantially different - designed to be more commercially relevant 423 from those used in Experiment 2 Substituting soya oil for lecithin oil at the same concentration 424 numerically reduced broiler growth and increased FCR until day 10 (1.45 soya oil vs 1.55 425 lecithin oil, $\mathrm{P}=0.161$ ), while weight at day 10 was $3 \%$ lower in birds fed on the lecithin oil diet 426 than diets formulated with soya oil. Though differences between unsupplemented soya and 427 lecithin oil treatments were not statistically significant, the large difference in FCR during the 428 starter phase is commercially important to overall production profitability. Similarly, Huang et 429 al. (2007) reported that complete replacement of the soybean oil with lecithin $(2 \%$ lecithin in 430 the diet) resulted in adverse effects. The adverse effect of lecithin on bird performance was 431 greatest in young birds, and after day 10 the gap in feed conversion ratio between soya oil and 432 lecithin oil diets narrowed (6.9\% increase in FCR lecithin vs soya to day $10,3.1 \%$ increase in 433 FCR lecithin vs soya day 10-21), with birds on all treatments performing similarly. Until 14 434 days of age, fat digestion is severely limited in chicks due to a lack of bile salt secretion 435 (Krogdahl, 1985), after which the rates of synthesis increase fourfold. Therefore, it is likely 436 that birds fed the lower available energy diets containing lecithin oil were able to achieve 437 compensatory growth once bile salt synthesis reached sufficient levels and fat digestion 438 improved (Krogdahl, 1985), thus closing the performance gap with those fed diets containing 439 soya oil, despite energy conversion efficiency rates remaining lower throughout the trial. 440 Future research on the comparative effects of lecithin and lysolecithin should continue to assess 441 the effect on performance and digestibility until slaughter, when the bird is physiologically 442 more mature. Meanwhile, the performance increases seen with supplemental lysolecithin are 443 in line with previous research, which has demonstrated improved weight gain and feed 444 conversion ratio (FCR) (Wealleans et al., 2019; Allahyari-Bake and Jahanian, 2017; Zaefarian 
445 et al., 2015; Zampiga et al., 20132016), while others have reported increases in apparent 446 metabolizable energy (AME) (Majdolhosseini et al., 2019; Melegy et al., 2010; Jansen et al., 447 2015).

448 To conclude, this study presents evidence that lysolecithins - but likely not lecithin 449 itself - are able to significantly improve the digestibility and energy values of feed, especially 450 in young broilers. These improvements may be due to a combined effect of lysophospholipids 451 on lipid hydrolysis and nutrient absorption, though further research is required to confirm the 452 multifactorial mode of action

ACKNOWLEDGEMENT

455 The authors wish to acknowledge the Institute for the Promotion of Innovation through Science 456 and Technology in Flanders (Project Number 110534, Brussels, Belgium) for financial support 457 for Experiments 1 and 2 of this paper.

REFERENCES

460 Allahyari-Bake, S., and R. Jahanian. 2016. "Effects of dietary fat source and supplemental 461 lysophosphatidylcholine on performance, immune responses, and ileal nutrient digestibility in 462 broilers fed corn/soybean meal-or corn/wheat/soybean meal-based diets." Poultry Science 96: $463 \quad 1149-1158$.

464 Blanch, A., A. C. Barroeta, M. D. Baucells, X. Serrano, and F. Puchal. 1996. "Utilization of 465 different fats and oils by adult chickens as a source of energy, lipid and fatty acids". Animal 466 Feed Science and Technology. 61:335-342.

467 Brautigan, D.L., R. Li, E. Kubicka, S.D. Turner, J.S. Garcia, M.L. Weintraut and E.A. Wong. 468 2017. "Lysolecithin as feed additive enhances collagen expression and villus length in the 469 jejunum of broiler chickens.” Poultry Science, p.pex078. 
470 Chen, C., B. Jung and W.K. Kim. 2019. "Effects of lysophospholipid on growth performance, 471 carcass yield, intestinal development, and bone quality in broilers.” Poultry Science. 98: 39024723913.

473 Chu, B.S., A. P. Gunning, G. T. Rich, M. J. Ridout, R. M. Faulks, M. S. J. Wickham, and P. J. 474 Wilde. 2010. "Adsorption of bile salts and pancreatic colipase and lipase onto 475 digalactosyldiacylglycerol and dipalmitoylphosphatidylcholine monolayers". Langmuir 26: $4769782-9793$.

477 Croom, W.J., J. Brake, B.A. Coles, G.B Havenstein, V.L. Christensen, B.W. McBride, E.D. 478 Peebles and I.L. Taylor. 1999. "Is intestinal absorption capacity rate-limiting for performance 479 in poultry?" Journal of Applied Poultry Research. 8: 242-252.

480 Huang, J., D. Yang, and T. Wang. 2007. "Effects of replacing soy-oil with soy-lecithin on 481 growth performance, nutrient utilization and serum parameters of broilers fed corn-based 482 diets". Asian-Australasian Journal of Animal Science. 20:1880-1886.

483 Honda, K., H. Kamisoyama, Y. Isshiki, and S. Hasegawa. 2009. "Effects of dietary fat levels 484 on nutrient digestibility at different sites of chicken intestines”. Journal of Poultry Science. $485 \quad 46: 291-295$.

486 Huang, J., D. Yang, S. Gao, and T. Wang. 2008. "Effects of soy lecithin on lipid metabolism 487 and hepatic expression of lipogenic genes in broiler chickens". Livestock Science. 118:53-60. 488 Jansen, M., F. Nuyens, J. Buyse, S. Leleu, and L. Van Campenhout. 2015. “Interaction between 489 fat type and lysolecithin supplementation in broiler feeds." Poultry Science 94: 2506-2515.

490 Joshi, A., S. G. Paratkar, and B. N. Thorat. 2006. "Modification of lecithin by physical, 387 491 chemical and enzymatic methods". European Journal of Lipid Science and Technology. $492 \quad 108: 363-373$ 
493 Karray, A., Zarai, Z., Gargouri, Y., Verger, R., and S. Bezzine. 2011.” Kinetic properties of 494 pancreatic and intestinal sPLA2 from chicken and mammals using the monomolecular film 495 technique”. Journal of Colloid and Interface Science. 363:620-625.

496 Krogdahl, A. 1985. "Digestion and absorption of lipids in poultry". Journal of Nutrition $497 \quad 115: 675-685$.

498 Lairon, D. 2009. Digestion and absorption of lipids. Pages 68-93 in Designing Functional 499 Foods, ed. J. McClements and E. Decker. Sawston, Cambridge.

500 Liu. D., and F. Ma. 2011. Soybean phospholipids. Pages 483-500 in Recent trends for 501 enhancing the diversity and quality of soybean products, ed. D. Krezhova. Intech, Rijeka, 502 Croatia.

503 Lo, C. M., and P. Tso. 2009. Physicochemical basis of the digestion and absorption of 504 triacylglycerol. Pages 94-125 in Designing functional foods, ed. J. McClements and E. Decker. 505 Sawston, Cambridge.

506 Lundbaek, J. A. 2006. "Regulation of membrane protein function by lipid bilayer elasticity: a 507 single molecule technology to measure the bilayer properties experienced by an embedded 508 protein”. Journal of Physics: Condensed Matter. 18:1305-1344

509 Lundbaek, J. A., and O. S. Andersen. 1994. "Lysophospholipids modulate channel function by 510 altering the mechanical properties of lipid bilayers". Journal of General Physiology. 104:64551173.

512 Maingret, F., A. J. Patel, F. Lesage, M. Lazdunski, and E. Honoré. 2000. "Lysophospholipids 513 open the two-pore domain mechano-gated $\mathrm{K}(+)$ channels TREK-1 and TRAAK". Journal of 514 Biological Chemistry. 275:10128-10133.

515 Maiorka, A., A. V. F. Da Silva, E. Santin, J. M. Pizauro, and M. Macari. 2004. "Broiler Breeder 516 Age and Dietary Energy Level on Performance and Pancreas Lipase and Trypsin Activities of 517 7-days Old Chicks”. International Journal of Poultry Science. 3:234-237. 
518 Maisonnier, S., J. Gomez, A. Brée, C. Berri, E. Baéza and B. Carré. 2003. "Effects of

519 microflora status, dietary bile salts and guar gum on lipid digestibility, intestinal bile salts, and

520 histomorphology in broiler chickens.” Poultry Science 82: 805-814.

521 Majdolhosseini, L., H.A. Ghasemi, I. Hajkhodadadi and M.H. Moradi. 2019. "Nutritional and

522 physiological responses of broiler chickens to dietary supplementation with de-oiled soyabean

523 lecithin at different metabolisable energy levels and various fat sources." British Journal of

$524 \quad$ Nutrition 122: 863-872.

525 Malaki, N.A., A. J. Wright, and M. Corredig. 2010. "Interfacial design of protein-stabilized

526 emulsions for optimal delivery of nutrients". Food Functions 1: 141 148.

527 Melegy T., N.F. Khaled, R. El-Bana, and H. Abdellatif. 2010. "Dietary fortification of a natural

528 biosurfactant, lysolecithin in broilers." African Journal of Agricultural Research 5: 28865292892.

530 Meng, X., B. A. Slominski, and W. Guenter 2004. "The effect of fat type, carbohydrase, and 531 lipase addition on growth performance and nutrient utilization of young broilers fed wheat532 based diets”. Poultry Science. 83:1718-1727.

533 Milatz, S., S.M. Krug, R. Rosenthal, D. Günzel, D. Müller, J.D. Schulzke, S. Amasheh and M. 534 Fromm. 2010. „Claudin-3 acts as a sealing component of the tight junction for ions of either 535 charge and uncharged solutes." Biochimica et Biophysica Acta (BBA)-Biomembranes, 1798: $536 \quad 2048-2057$.

537 Myers, W.D., P.A. Ludden, V. Nayigihugu and B.W. Hess. 2004. "Technical note: a procedure 538 for the preparation and quantitative analysis of samples for titanium dioxide." Journal of 539 Animal Science 82:179-183.

540 Nik, A.M., A.J. Wright and M. Corredig. 2010. "Interfacial design of protein-stabilized 541 emulsions for optimal delivery of nutrients". Food Functions 1: 141-148. 
542 Papadopoulos, G.A., T. Poutahidis, S. Chalvatzi, M. Di Benedetto, A. Hardas, V. Tsiouris, I

543 Georgopoulou, G. Arsenos and P.D. Fortomaris. 2018. "Effects of lysolecithin

544 supplementation in low-energy diets on growth performance, nutrient digestibility, viscosity 545 and intestinal morphology of broilers.” British Poultry Science. 59: 232-239.

546 Papadopoulos, G.A., K. Müller, D. Schertling and M. Di Benedetto. 2014. "Supplementation

547 of lysolecithin in combination with a multi-non-starch polysaccharides enzyme improves the

548 feed efficiency during the post-weaning period in piglets". Acta Agriculturae Scandinavica,

549 Section A-Animal Science. 64(2):130-136.

550 Polin, D., T. L. Wing, P. Ki, and K. E. Pell. 1980. "The effect of bile acids and lipase on 551 absorption of tallow in young chicks”. Poultry Science. 59:2738-2743.

552 Rampone, A.J. 1961. "Rate of Fat Uptake by Intestinal Lymphatics." Proceedings of the 553 Society for Experimental Biology and Medicine. 108: 278-282.

554 Raju, M. V. L. N., S. V. R. Rao, P. P. Chakrabarti, B. V. S. K. Rao, A. K. Panda, B. L. A. P. 555 Devi, V. Sujatha, J. R. C. Reddy, G. Shyam Sunder, and R. B. N. Prasad. 2011. "Rice bran 556 lysolecithin as a source of energy in broiler chicken diet”. British Poultry Science. 52:769-774.

557 Ravindran, V., P. Tancharoenrat, F. Zaefarian, and G. Ravindran. 2016. "Fats in poultry 558 nutrition: Digestive physiology and factors influencing their utilisation." Animal Feed Science and Technology 213: 1-21.

560 Reis, P., K. Holmberg, H. Watzke, M. E. Leser, and R. Miller. 2009. "Lipases at interfaces: a 561 review". Advanced Colloid Interface Science. 147: 237-250.

562 Reis, P., H. Watzke, M. Leser, K. Holmberg, and R. Miller. 2010. "Interfacial mechanism of 563 lipolysis as self-regulated process". Biophysical Chemistry. 147: 93-103.

564 Roy, A., S. Haldar, S. Mondal, and T. K. Ghosh. 2010. "Effects of supplemental exogenous 565 emulsifier on performance, nutrient metabolism, and serum lipid profile in broiler chickens". 566 Veterinary Medicine International. doi:10.4061/2010/262604. 
567 Saleh, E. A., S. E. Watkins, A. L. Waldroup, and P. W. Waldroup. 2004. "Effects of dietary 568 nutrient density on performance and carcass quality of male broilers grown for further 569 processing.” International Journal Poultry Science 3: 1-10.

570 Short, F. J., P. Gorton, J. Wiseman and K.N. Boorman. 1996. "Determination of titanium 571 dioxide added as an inert marker in chicken digestibility studies." Animal Feed Science and 572 Technology 59:215-221.

573 Sugawara, T., M. Kushiro, H. Zhang, and E. Nara. 2001. "Nutrient Interactions and Toxicity 574 Lysophosphatidylcholine Enhances Carotenoid Uptake from Mixed Micelles by Caco-2 575 Human Intestinal Cells”. Journal of Nutrition. 131:2921-2927.

576 Tancharoenrat, P., V. Ravindran, F. Zaefarian, and G. Ravindran. 2013. "Influence of age on 577 the apparent metabolisable energy and total tract apparent fat digestibility of different fat 578 sources for broiler chickens”. Animal Feed Science and Technology. 186:186-192.

579 Van Nieuwenhuyzen, W., and M. C. Tomás. 2008. "Update on vegetable lecithin and 580 phospholipid technologies”. European Journal of Lipid Science and Technology. 110:472-486.

581 Vors, C., P. Capolino, C. Guérin, E. Meugnier, S. Pesenti, M. A. Chauvin, J. Monteil, N. 582 Peretti, M. Cansell, F. Carrière, and M. C. Michalski. 2012. "Coupling in vitro gastrointestinal 583 lipolysis and Caco-2 cell cultures for testing the absorption of different food emulsions". Food 584 Functions. 3:537-46

585 Wang, Q.Q., S.F. Long, J.X. Hu, M. Li, L. Pan, and X.S Piao. 2019. "Effects of dietary 586 lysophospholipid complex supplementation on lactation performance, and nutrient digestibility 587 in lactating sows”. Animal Feed Science and Technology. 251:56-63

588 Wealleans, A.L; Jansen, M and di Benedetto, M., 2019. "Addition of lysolecithin to broiler 589 diets improves growth performance across fat levels and sources”. British Poultry Science. In 590 Press. 
591 Wendel, A. 2000. Lecithin. Pages 1-19 in Kirk-Othmer Encyclopedia of Chemical Technology. 592 Ed. John Wiley \& Sons, Inc., New York.

593 Wiseman, J., F. Salvador, and J. Craigon. 1991. "Prediction of the apparent metabolizable 594 energy content of fats fed to broiler chickens." Poultry Science 70(7): 1527-1533.

595 Zaefarian, F., L.F. Romero, and V. Ravindran. 2015. "Influence of high dose of phytase and 596 an emulsifier on performance, apparent metabolisable energy and nitrogen retention in broilers 597 fed on diets containing soy oil or tallow.” British Poultry Science 56: 590-597.

598 Zampiga, M., A. Meluzzi, and F. Sirri. 2016. "Effect of dietary supplementation of 599 lysophospholipids on productive performance, nutrient digestibility and carcass quality traits 600 of broiler chickens.” Italian Journal of Animal Science 15: 521-528.

601 Zhang, B., L. Haitao, D. Zhao, Y. Guo, and A. Barri. 2011. "Effect of fat type and 602 lysophosphatidylcholine addition to broiler diets on performance, apparent digestibility of fatty 603 acids, and apparent metabolizable energy content." Animal Feed Science and Technology 163: 604 177-184.

605 Zhao, P.Y., Z.F. Zhang, R.X. Lan, W.C. Liu and I.H Kim. 2017. "Effect of lysophospholipids 606 in diets differing in fat contents on growth performance, nutrient digestibility, milk 607 composition and litter performance of lactating sows”. animal, 11: 984-990. 
609 Table 1. Effect of soybean lecithin and soybean lysolecithin on the apparent first-order rate

610 constant $(\mathrm{k}, \times 103 \mathrm{~min}-1)$ of triglyceride hydrolysis and diglyceride, monoglyceride and free

611 fatty acid release during in vitro digestion of palm oil (Experiment 1)

\begin{tabular}{|c|c|c|c|c|}
\hline & $\begin{array}{l}\text { Triglyceride } \\
\text { hydrolysis }\end{array}$ & $\begin{array}{l}\text { Diglyceride } \\
\text { release }\end{array}$ & $\begin{array}{l}\text { Monoglyceride } \\
\text { release }\end{array}$ & $\begin{array}{l}\text { Free fatty acid } \\
\text { release }\end{array}$ \\
\hline \multicolumn{5}{|l|}{ Treatment $^{1}$} \\
\hline Palm oil & $9.73^{b}$ & $1.15^{\mathrm{c}}$ & $2.91^{b}$ & $10.85^{b}$ \\
\hline Palm oil + lecithin ${ }^{2}$ & $8.41^{\mathrm{c}}$ & $1.58^{b}$ & $2.23^{\mathrm{c}}$ & $9.49^{\mathrm{b}}$ \\
\hline Palm oil + lysolecithin 3 & $11.67^{\mathrm{a}}$ & $1.70^{\mathrm{a}}$ & $3.07^{\mathrm{a}}$ & $12.49^{\mathrm{a}}$ \\
\hline Pooled SEM & 0.28 & 0.02 & 0.04 & 0.45 \\
\hline$P$-value & 0.001 & 0.000 & 0.000 & 0.009 \\
\hline
\end{tabular}

612 a-c Values within columns with different superscripts are significantly different $(P<0.05)$.

$613{ }^{1}$ Data are means of three observations per treatment.

$614 \quad 2,3$ Lecithin and lysolecithin were applied at $1 \mathrm{~g}$, dispersed into $49 \mathrm{~g}$ of oil 
616 Table 2. Ingredients and nutrient composition of the basa $1^{1}$ experimental diet (Experiment 2)

\begin{tabular}{lc}
\hline Item $(\mathrm{g} / \mathrm{kg}$, unless noted) & Starter diet \\
\hline Ingredient & 452.9 \\
Corn & 100.0 \\
Wheat & 363.2 \\
Soybean meal $(45.3 \% \mathrm{CP})$ & 40.0 \\
Palm oil & 13.6 \\
Monocalcium phosphate & 10.0 \\
Vitamin and mineral premix ${ }^{2}$ & 3.0 \\
Methionine & 2.3 \\
Lysine HCl & 0.6 \\
Threonine & 6.8 \\
Limestone & 2.0 \\
NaCl & 2.5 \\
NaHCO & 3.0 \\
TiO & \\
& \\
Calculated composition & \\
AMEn (MJl/kg) & 11.41 \\
Crude fiber & 3.19 \\
Lysine & 1.15 \\
Methionine + cysteine & 0.86 \\
Threonine & 0.75 \\
Calcium & 0.85 \\
Total phosphorus & 0.69 \\
Available phosphorus & 0.40 \\
Natrium & 0.15 \\
Analyzed composition & \\
Dry matter & 90.43 \\
Crude protein & 23.05 \\
Crude fat & 7.25 \\
TiO & \\
Gross energy $(\mathrm{MJ} / \mathrm{kg})$ & 17.50 \\
\hline
\end{tabular}

$617{ }^{1}$ For experimental treatments, lysolecithin was added on top of the specified basal diet at 250 618 ppm

$6192^{2}$ Supplied per kilogram of diet: manganese, $99 \mathrm{mg}$; zinc, $60 \mathrm{mg}$; iron, $49 \mathrm{mg}$; copper, $20 \mathrm{mg}$; 620 iodine, $1.2 \mathrm{mg}$; selenium, $0.4 \mathrm{~g}$; vitamin A, 13,500 IU (retinyl acetate); vitamin E, 55 IU 621 (DL- $\alpha$-tocopheryl acetate); cholecalciferol, $75 \mu \mathrm{g}$; vitamin $\mathrm{B}_{1}, 2 \mathrm{mg}$; vitamin $\mathrm{B}_{2}, 5 \mathrm{mg}$; 622 vitamin $B_{3}, 30 \mathrm{mg}$; vitamin $B_{5}, 15 \mathrm{mg}$; vitamin $B_{6}, 4 \mathrm{mg}$; vitamin $B_{12}, 2 \mathrm{mg}$; vitamin $\mathrm{K}, 2.5$ $623 \mathrm{mg}$; folic acid, $1 \mathrm{mg}$; biotin; $0.2 \mathrm{mg}$; choline, $600 \mathrm{mg}$; etoxyquine, $33 \mathrm{mg}$; butylated 624 hydroxytoluene (BHT), $0.4 \mathrm{mg}$; propyl gallate, $0.12 \mathrm{mg}$; citric acid, $0.69 \mathrm{mg}$; sepiolite, $4 \mathrm{mg}$. $625{ }^{3}$ Values represent the mean of the three experimental diets. 
628 Table 3. Effect of soybean lecithin and soybean lysolecithin on the apparent faecal dry matter

629 and crude fat digestibility, nitrogen retention and AMEn of young broilers fed a palm oil rich

$630 \operatorname{diet}($ Experiment 2)

\begin{tabular}{|c|c|c|c|c|}
\hline & \multicolumn{2}{|c|}{ Digestibility (\%) } & \multirow{2}{*}{$\begin{array}{l}\text { N-retention } \\
\text { (g/kg DM) }\end{array}$} & \multirow{2}{*}{$\begin{array}{l}\text { AMEn } \\
(\mathrm{MJ} / \mathrm{kg} \mathrm{DM})\end{array}$} \\
\hline & DM & Crude fat & & \\
\hline \multicolumn{5}{|l|}{ Dietary treatment ${ }^{1}$} \\
\hline Basal diet & $69.85^{b}$ & $69.52^{b}$ & $27.03^{\mathrm{ab}}$ & $13.03^{b}$ \\
\hline Basal diet + lecithin & $69.47^{b}$ & $66.32^{\mathrm{c}}$ & $25.26^{b}$ & $13.03^{b}$ \\
\hline Basal diet + lysolecithin & $72.88^{\mathrm{a}}$ & $71.77^{\mathrm{a}}$ & $27.75^{\mathrm{a}}$ & $13.50^{\mathrm{a}}$ \\
\hline Pooled SEM & 0.16 & 0.71 & 0.53 & 0.16 \\
\hline$P$-value & 0.000 & 0.003 & 0.039 & 0.008 \\
\hline
\end{tabular}

631 a-c Values within columns with different superscripts are significantly different $(P<0.05)$.

$632{ }^{1}$ Data are means of three observations per treatment. 
634 Table 4. Fatty acid distribution (\%) in the ether extracts of the faeces of young broilers fed a 635 basal palm oil diet, the basal diet supplemented with lecithin and the basal diet supplemented 636 with lysolecithin (Experiment 2)

\begin{tabular}{lccccc}
\hline \hline Fatty acid ${ }^{12}$ & Basal diet & $\begin{array}{c}\text { Basal diet } \\
+ \text { lecithin }\end{array}$ & $\begin{array}{c}\text { Basal Diet } \\
+ \text { lysolecithin }\end{array}$ & $\begin{array}{c}\text { Pooled } \\
\text { SEM }\end{array}$ & $P$-value \\
\hline C16:0 & 40.59 & 40.47 & 41.23 & 0.69 & $\mathrm{NS}$ \\
C18:0 & 6.29 & 6.89 & 6.91 & 0.15 & $\mathrm{NS}$ \\
C18:1 $(\omega-9)$ & 23.71 & 23.47 & 23.75 & 0.12 & $\mathrm{NS}$ \\
C18:2 $(\omega-6)$ & 26.01 & 26.46 & 25.55 & 0.75 & $\mathrm{NS}$ \\
C18:3 $(\omega-3)$ & 0.69 & 0.71 & 0.65 & 0.02 & $\mathrm{NS}$ \\
Total unsaturated fatty acids & 49.34 & 49.13 & 49.83 & 0.84 & $\mathrm{NS}$ \\
Total saturated fatty acids & 50.66 & 50.87 & 50.17 & 0.84 & $\mathrm{NS}$ \\
Ratio unsaturated / saturated & 1.03 & 1.04 & 1.01 & 0.03 & $\mathrm{NS}$ \\
\hline
\end{tabular}

$637{ }^{1}$ Fatty acids that are not listed were present for less than $0.5 \%$ in all samples.

$638 \quad 2$ Data are means of three observations per treatment. 
639 Table 5. Ingredients and nutrient composition of the basal experimental $\operatorname{diets}^{1}$ (Experiment 3 )

\begin{tabular}{lcc}
\hline \hline Item $(\mathrm{g} / \mathrm{kg}$, unless noted) & Soybean Oil & Lecithin Oil \\
\hline Wheat & 541.6 & 541.6 \\
Pura $^{2}$ & 100.0 & 100.0 \\
Soybean Meal (46.6\% CP) & 304.0 & 304.0 \\
Soybean Oil & 20.0 & -- \\
Lecithin Oil & -- & 20.0 \\
Limestone & 5.6 & 5.6 \\
Salt & 1.6 & 1.6 \\
Sodium Bicarbonate & 2.8 & 2.8 \\
DCP & 12.4 & 12.4 \\
Lysine HCl & 2.7 & 2.7 \\
DL Methionine & 3.4 & 3.4 \\
Threonine & 1.0 & 1.0 \\
Ronozyme P5000 & 0.15 & 0.15 \\
Ronzyme WX & 0.15 & 0.15 \\
Vit/Min Premix & 3.63 & 4.63
\end{tabular}

Calculated composition, $\%$

$\mathrm{ME}, \mathrm{MJ} / \mathrm{kg}$

$12.609 \mathrm{MJ} / \mathrm{kg}$

Crude Protein

22.47

Crude Fat

6.207

Crude Fibre

3.38

Dig Lys

1.247

Dig Met

0.623

Dig Met+Cys

0.938

$\mathrm{Ca}$

0.898

Av P

0.449

$\mathrm{Na}$

0.150

$640{ }^{1}$ Lysolecithins (as LYSOFORTE ${ }^{\circledR}$ EXTEND) were added on top of the basal diet formulations 641 at $500 \mathrm{ppm}$

6422 Pura is a commercially available blend of whole rapeseed and pulses (field beans or peas) which has been ground, heat treated and pelleted. Typical analysis $21 \%$ oil, $21 \%$ protein.

644 3Supplied per kilogram of diet: manganese, $99 \mathrm{mg}$; zinc, $60 \mathrm{mg}$; iron, $49 \mathrm{mg}$; copper, $20 \mathrm{mg}$; 645 iodine, $1.2 \mathrm{mg}$; selenium, $0.4 \mathrm{~g}$; vitamin A, 13,500 IU (retinyl acetate); vitamin E, $55 \mathrm{IU}$ 646 (DL- $\alpha$-tocopheryl acetate); cholecalciferol, $75 \mu \mathrm{g}$; vitamin $\mathrm{B}_{1}, 2 \mathrm{mg}$; vitamin $\mathrm{B}_{2}, 5 \mathrm{mg}$; 647 vitamin $\mathrm{B}_{3}, 30 \mathrm{mg}$; vitamin $\mathrm{B}_{5}, 15 \mathrm{mg}$; vitamin $\mathrm{B}_{6}, 4 \mathrm{mg}$; vitamin $\mathrm{B}_{12}, 2 \mathrm{mg}$; vitamin $\mathrm{K}, 2.5$ $648 \mathrm{mg}$; folic acid, $1 \mathrm{mg}$; biotin; $0.2 \mathrm{mg}$; choline, $600 \mathrm{mg}$; etoxyquine, $33 \mathrm{mg}$; butylated 649 hydroxytoluene (BHT), $0.4 \mathrm{mg}$; propyl gallate, $0.12 \mathrm{mg}$; citric acid, $0.69 \mathrm{mg}$; sepiolite, $4 \mathrm{mg}$. 
650 Table 6. Growth performance of young broilers from day 0-21 fed diets formulated with soya oil or lecithin oil, with or without supplemental 651 lysolecithin. (Experiment 3).

\begin{tabular}{|c|c|c|c|c|c|c|}
\hline & Soya Oil & $\begin{array}{c}\text { Soya Oil } \\
+ \text { Lysolecithin } \\
\end{array}$ & Lecithin Oil & $\begin{array}{c}\text { Lecithin Oil } \\
+ \text { Lysolecithin }\end{array}$ & $\begin{array}{l}\text { Pooled } \\
\text { SEM }\end{array}$ & P-value \\
\hline \multicolumn{7}{|l|}{ Day 0-10 } \\
\hline Weight at day $0, \mathrm{~g}$ & 38.3 & 38.3 & 38.6 & 38.9 & 0.72 & 0.906 \\
\hline Average daily gain, $\mathrm{g}$ & 21.2 & 21.5 & 20.8 & 22.0 & 0.41 & 0.198 \\
\hline Average daily feed intake, $g$ & 32.0 & 29.5 & 32.3 & 31.6 & 1.13 & 0.326 \\
\hline FCR & 1.45 & 1.36 & 1.55 & 1.43 & 0.060 & 0.161 \\
\hline \multicolumn{7}{|l|}{ Day 10-21 } \\
\hline Weight at day $10, \mathrm{~g}$ & $256.2^{\mathrm{ab}}$ & $258.9^{\mathrm{ab}}$ & $248.9^{\mathrm{b}}$ & $263.8^{\mathrm{a}}$ & 3.18 & 0.015 \\
\hline Average daily gain, $\mathrm{g}$ & 61.3 & 61.4 & 59.4 & 63.4 & 0.11 & 0.105 \\
\hline Average daily feed intake, $g$ & 80.6 & 81.9 & 79.9 & 83.9 & 1.24 & 0.183 \\
\hline FCR & 1.31 & 1.33 & 1.35 & 1.33 & 0.020 & 0.723 \\
\hline \multicolumn{7}{|l|}{ Day 0-21 } \\
\hline Weight at day $21, \mathrm{~g}$ & $934.1^{\mathrm{ab}}$ & $941.6^{\mathrm{ab}}$ & $906.9^{b}$ & $961.7^{\mathrm{a}}$ & 1.38 & 0.047 \\
\hline Average daily gain, $\mathrm{g}$ & $42.5^{\mathrm{ab}}$ & $42.8^{\mathrm{ab}}$ & $41.3^{\mathrm{b}}$ & $43.9^{\mathrm{a}}$ & 0.50 & 0.036 \\
\hline Average daily feed intake, $g$ & 56.5 & 56.5 & 57.0 & 58.6 & 0.89 & 0.356 \\
\hline FCR & 1.33 & 1.32 & 1.38 & 1.33 & 0.024 & 0.225 \\
\hline Energy conversion rate $(\mathrm{MJ} / \mathrm{kg} \mathrm{BWG})$ & 16.04 & 15.88 & 16.60 & 16.06 & -- & -- \\
\hline
\end{tabular}

${ }^{1}$ Data are means of twelve observations per treatment. 
653 Figure 1. Hydrolysis of (A) triglycerides and accumulation of (B) free fatty acids, (C)

654 diglycerides and (D) monoglycerides during the in vitro hydrolysis of palm oil (solid line),

655 palm oil with soybean lecithin (dotted line) and palm oil with soybean lysolecithin (dashed

656 line). The experimental treatments were carried out in triplicate. The mean concentrations of

657 the lipids $(\mathrm{mg} / \mathrm{ml})$ are given over time $(\mathrm{min})$, with error bars indicating the standard error

658 values. Statistical analysis of the treatments is performed based on apparent rate constants (see

659 Table 1). For enzyme kinetic comparison, apparent rate constants are used. (Experiment 1).

660

661 Figure 2. Absorption of monoglycerides (white bars) and free fatty acids (grey bars) generated

662 during in vitro hydrolysis of palm oil, palm oil with soybean lecithin and palm oil with soybean

663 lysolecithin by differentiated Caco-2 monolayers and expressed as percentage of applied

664 monoglycerides end free fatty acids. Data are means of three or more observations per

665 treatment, with error bars indicating the standard error values. (Experiment 1).

666 
1 Lysolecithin, but not lecithin, improves nutrient digestibility and growth rates in young 2 broilers

$\mathrm{AL}$ Wealleans $^{\dagger 1}$, J Buyse ${ }^{\# \dagger}$, D Scholey*, L van Campenhout ${ }^{\ddagger}$, E Burton*, M Di Benedetto ${ }^{\dagger}, \mathrm{S}$ Pritchard $^{\#}$, F Nuyens ${ }^{\dagger}$, and M Jansen ${ }^{\dagger \#}$

6

$7 \dagger$ Kemin Europa NV, Herentals, Belgium

8 \# Division Animal and Human Health Engineering, Department of Biosystems, KU Leuven, 9 Geel, Belgium

$10 \ddagger$ Leuven Food Science and Nutrition Research Center (LFoRCe), Leuven, Belgium

$11 *$ Nottingham Trent University, Southwell, United Kingdom

$12 \S$ Lab4Food, Cluster for Bioengineering Technology (CBeT), Department of Microbial and

13 Molecular Systems (M2S), KU Leuven, Geel, Belgium

14 \# Premier Nutrition, Rugeley, United Kingdom

Email:

Alexandra L Wealleans

Telephone:

Kemin Animal Nutrition and Health

Toekomstlaan 42, 2200 Herentals

Belgium 


\section{ABSTRACT}

1. The potential of lecithin and lysolecithin to improve lipid digestion and growth performance was investigated in three experiments: 1 . an in vitro model that mimics the intestinal conditions of the chick, 2. a digestibility trial with chicks (5-7 days of age), and 3. a performance trial until 21 days of age.

2. In experiment 1 , palm oil $(\mathrm{PO})$, palm oil with lecithin $(\mathrm{PO}+\mathrm{L})$, and palm oil with lysolecithin $(\mathrm{PO}+\mathrm{LY})$ were subjected to in vitro hydrolysis and applied to Caco-2 monolayers to assess lipid absorption.

3. The in vitro hydrolysis rate of triglycerides was higher in $\mathrm{PO}+\mathrm{LY}\left(\mathrm{k}=11.76 \times 10^{3} / \mathrm{min}\right)$ than in either $\mathrm{PO}\left(\mathrm{k}=9.73 \times 10^{3} / \mathrm{min}\right)$ or $\mathrm{PO}+\mathrm{L}\left(\mathrm{k}=8.41 \times 10^{3} / \mathrm{min}\right)$, and the absorption of monoglycerides and free fatty acids was highest $(\mathrm{P}<0.01)$ for $\mathrm{PO}+\mathrm{LY}$. In experiment 2, 90 broilers were assigned to three dietary treatments: a basal diet with $4 \%$ palm oil, and the basal diet supplemented with either $250 \mathrm{ppm}$ lecithin or lysolecithin.

4. ATTD of crude fat was higher in broilers supplemented with lysolecithin, but was lower in broilers supplemented with lecithin. DM digestibility and AMEn in birds supplemented with lysolecithin were significantly higher $(3.03 \%$ and $0.47 \mathrm{MJ} / \mathrm{kg}$, respectively).

5. In experiment 3, 480 broilers were randomly allocated to four dietary treatments: basal diet with soybean oil (2\%), basal diet with lecithin (2\%), soybean oil diet with $250 \mathrm{ppm}$ lysolecithin, or lecithin oil diet with 250 ppm lysolecithin.

6. Lecithin diets significantly reduced weight at day 10 and 21 compared with soybean oil. However, the addition of lysolecithin to lecithin-containing diets significantly improved bird performance.

7. The results of these studies showed that, in contrast to lecithin, lysolecithin was able to significantly improve the digestibility and energy values of feed in young broilers. 
KEYWORDS: broiler; digestibility; fat; lecithin; lysolecithin; performance

\section{INTRODUCTION}

After hatch, lipid digestion in young birds is physiologically limited, and is a target for improvement and support. Roy et al. (2010) have ascribed the inefficient digestion and absorption of lipids by young chickens to a combination of a poor duodenal secretion of lipase, a low level of lipase activity and a reduced rate of bile salt synthesis. Kroghdahl (1985) and Maiorka et al. (2004) showed, however, that lipase concentration and activity in young chickens (at seven days of age) are modulated according to the inclusion level of fats in the diet. Moreover, in a study of Meng et al. (2004), lipase addition at $0.2 \mathrm{~g} / \mathrm{kg}$ did not affect the apparent fat digestibility in broilers aged one to 14 days of age. Therefore, the inability to utilise fats has been attributed to low bile salt concentrations in the intestines, rather than to deficiencies in lipase secretion or activity (Maiorka et al., 2004; Maisonnier et al., 2003). Although dietary supplementation of bile salt has been shown to improve lipid utilisation in chickens (Krogdahl, 1985; Polin et al 1980), supplementation is generally not applied on a commercial scale due to economic considerations (Roy et al., 2010).

One strategy for improving fat digestion is the dietary application of molecules with proven ability to improve lipid digestion, for example lecithin and its derivative, lysolecithin. Huang et al. (2007) showed that, in diets supplemented with $2 \%$ of soybean oil, replacement of $25 \%$ of the soybean oil with soybean lecithin $(0.5 \%$ lecithin in the diet $)$ improved crude fat digestion and performance in broilers. On the other hand, complete replacement of the soybean oil with lecithin ( $2 \%$ lecithin in the diet) resulted in adverse effects. Moreover, in a study of Blanch et al. (1996) the AME of the basal diet containing tallow as the main fat source was not improved by the addition of $0.2 \%$ soybean lecithin. 
76 Lysolecithins are produced by phospholipase which cleaves one hydrophobic fatty acid from phospholipids (Joshi et al., 2006). This changes the stereochemical structure of phospholipids in lecithin into lysophospholipids. The resulting lysolecithin mixture has an increased hydrophilic-lipophilic balance (Van Nieuwenhuyzen and Tomás, 2008) and lower critical micelle concentration ( 0.02 to $0.2 \mathrm{mM} / 1)$. Both phospholipids and lysophospholipids consist of a hydrophilic head group (phosphatidyl substituent) and a hydrophobic tail (fatty acid chains). But, due to the removal of one fatty acid, lysophospholipids are more hydrophilic and thus have better oil-in-water emulsifying properties than phospholipids (Joshi et al., 2006; Liu and Ma, 2011). In the animal, the pancreas secretes native phospholipase (EC 3.1.1.4) to convert the phospholipids secreted by the gall bladder into lysophospholipids (Karray et al., 2011). These have been shown to play an important role in mixed micelle formation (Lo and Tso, 2009). Therefore, it can be hypothesised that lysolecithin possesses a greater ability to improve the digestion of fats and oils than lecithin. Inclusion of 3.2\% of rice bran lysolecithin in a broiler feed formulated with rice bran oil increased the crude fat digestibility (Raju et al., 2011). Additionally, Zhang et al. (2011) observed increased fatty acid digestibility in broilers using $0.125 \%$ of soybean lysolecithin in partial replacement for soybean oil, tallow and poultry fat. These improvements in digestibility consistently lead to improved growth performance and efficiency in growing broilers (Wealleans et al., 2019), as well as in other species (Wang et al., 2019; Zhao et al., 2017; Papadopoulos et al., 2014).

The limited comparative studies available on lecithin and lysolecithin application in broiler diets have all been performed with birds of 14 days of age or older. Therefore, the potential of both lecithin and lysolecithin from soybean to improve lipid digestion was investigated in three experiments: an in vitro model, a digestibility trial with young broilers (5-7 days of age), and a performance trial until 21 days of age. 
101

102

103

104

105

106

107

108

109

110

111

112

113

114

115

116

117

\section{METHODS AND MATERIALS}

\section{Experiment 1: In vitro fat absorption}

Crude palm oil (single batch) was sourced from a commercial feed mill in Belgium. The FA composition of the palm oil was analysed (ISO, 2002, 17764). Soybean lecithin and lysolecithin were sourced from Kemin Europa NV (Herentals, Belgium). Lecithin and lysolecithin were analysed for their phospho- and lysophospholipid content by phosphorus-31 nuclear magnetic resonance spectroscopy $\left({ }^{31} \mathrm{P}-\mathrm{NMR}\right.$, Spectral Service AG, Cologne, Germany).

The lipid hydrolysis model, previously employed by Jansen et al. (2015), was slightly modified. Briefly, $1 \mathrm{~g}$ of lecithin or lysolecithin were first dispersed into $49 \mathrm{~g}$ of palm oil. Fasted state, simulated intestinal fluid (FaSSIF) was prepared by adding $2.24 \mathrm{~g}$ of FaSSIF powder (Biorelevant.com Ltd, Croydon, United Kingdom) into $1 \mathrm{~L}$ of phosphate buffer (35 $\mathrm{mM}, \mathrm{pH}$ 6.5) containing $106 \mathrm{mM} \mathrm{NaCl}$. According to the manufacturer, the FaSSIF contained $3 \mathrm{mM}$ bile salt (sodium taurocholate). Aliquots of $0.25 \mathrm{~g}$ of each of the respective fat treatments and $14.75 \mathrm{ml}$ of FaSSIF were added into $50 \mathrm{ml}$ centrifuge tubes. The content of each tube was mixed for 30 seconds with a high shear mixer (24000 rpm; IKA ultra-turrax T18, Staufen, Germany). Next, $24 \mathrm{mg}$ of pancreatin (P7545, Sigma Aldrich) was added to each tube and incubated for two hours at $40^{\circ} \mathrm{C}$ while shaking $(250 \mathrm{rpm})$. The final contents in the digests were $106 \mathrm{mM} \mathrm{NaCl}, 1.6 \mathrm{~g} / 1$ pancreatin, $1.6 \mathrm{~g} / \mathrm{l}$ bile salts and $16.7 \mathrm{~g} / 1$ palm oil. At $0,15,30,60,90$ and 120 minutes of incubation, a $0.5 \mathrm{ml}$ aliquot of each digest was taken and diluted in $9.5 \mathrm{ml}$ tetrahydrofuran (HPLC grade, VWR International, Leuven, Belgium) to inactivate the enzymes and prepare the appropriate dilution for lipid analysis. Each digestion was performed in triplicate. Samples of the digests were submerged in liquid nitrogen and stored at $-180^{\circ} \mathrm{C}$ until the absorption experiments started. 
125 Human colonic adenocarcinoma cells (Caco-2) were obtained from the European Collection of 126 Cell Cultures (Public Health England, Porton Down, Salisbury, UK). Caco-2 cell work stock 127 was used between passages 54 and 60. Cells were cultured in Dulbecco's modified eagle 128 medium supplemented with $100 \mathrm{ml} / 1$ heat-inactivated foetal bovine serum (Hyclone, Thermo 129 scientific, Leuven, Belgium), $10 \mathrm{ml} / 1$ non-essential amino acids, $100 \mathrm{U} / \mathrm{ml}$ of penicillin and $130100 \mathrm{U} / \mathrm{ml}$ of streptomycin. The cells were maintained at $37^{\circ} \mathrm{C}$ in a humidified atmosphere of $1315 \% \quad \mathrm{CO}_{2}$ and routinely passaged. Unless stated otherwise, the cell culture media and 132 supplements were provided by Westburg (Leusden, The Netherlands).

133 Caco-2 cells were seeded on collagen-coated Transwell-COL inserts $\left(1.12 \mathrm{~cm}^{2}\right.$, pore size 0.4 $134 \mu \mathrm{m}$, Corning Costar Corporation, Cambridge, MA) in 24-well plates at a density of $2 \times 10^{5}$ 135 cells per insert and incubated for 21 days to allow the cells to differentiate. During incubation absorption experiment performed in at least three replicates. In each sample obtained during the in vitro lipid digestion, the degree of lipid hydrolysis was analysed by HPLC. The lipids were separated into triglycerides (TG), diglycerides (DG), MG and FFA by a gel permeation column (PL 1110-6520, $5 \mu \mathrm{m} \mathrm{100A} 300$ x $7.5 \mathrm{~mm}$, Agilent 
150 (ELSD 85, VWR International). Tetrahydrofuran was used as the mobile phase at a flow rate 151 of $0.5 \mathrm{ml} / \mathrm{min}$. Likewise, samples obtained with the lipid absorption model were analysed for 152 their MG and FFA content.

153 The hydrolysis of palm oil at each sample time was calculated and the apparent rate constant 154 for TG hydrolysis and FFA, MG and DG release were determined as described by Jansen et al. 155 (2015). The absorption of MG (g/g) in each well was calculated as follows: MG absorption $=\frac{M G_{0}-M G_{60}}{M G_{0}}$

157 where ${ }^{M G_{0}}$ and $M G_{60}$ are the respective MG contents (g/l) before and after 60 minutes of 158 incubation. Correspondingly, FFA absorption (g/g) was calculated from the respective FFA 159 contents.

160 For statistical comparison of the in vitro hydrolysis, the apparent rate constants for TG 161 hydrolysis and FFA, MG and DG release and the MG and FFA absorption were analysed as a 162 factorial arrangement. Analysis of variance (ANOVA) of the experimental treatments was done 163 with STATGRAPHICS Centurion XVI software (Statpoint Technologies Inc., Warrenton, 164 VA), and means were separated by the least significant difference procedure. All statements of 165 significance were based on a P-value equal to or less than 0.05 .

Experiment 2: Digestibility

168 A broiler digestibility trial was performed at the experimental research facility of the 169 Laboratory of Livestock Physiology (Leuven, Belgium). The experiments were conducted in 170 strict accordance with the European Communities Council Directive (2003/65/EC) and were 171 approved by the Ethical Commission for Experimental Use of Animals of the KU Leuven 172 (P213/2015). A total of 90, one-day-old male Ross 308 chickens were obtained from 173 Belgabroed NV (Merksplas, Belgium) and assigned randomly at day zero, in groups of ten 
174 birds, to three dietary treatments; a basal diet without lecithin and lysolecithin, the basal diet

175

176

177 supplemented with $250 \mathrm{ppm}$ lecithin and the basal diet supplemented with $250 \mathrm{ppm}$ lysolecithin. Lecithin and lysolecithin were applied to diets at the same rate in order to allow direct comparison of the effects of phospholipids and lysophospholipids.

To prepare the experimental diet (Table 1), all raw materials were milled together to obtain homogeneous batches. Next, the feed was divided into three batches and successively mixed in a small mixer with different premixes in order to produce the experimental diets. Titanium dioxide (E171, IMCD Benelux N.V., Mechelen, Belgium) was added to all diets as an indigestible marker at an inclusion rate of $3 \mathrm{~g} / \mathrm{kg}$. All diets were fed in mash form and contained a commercial enzyme blend (KEMZYME Plus Concentrate Dry 50 ppm, Kemin Europa NV) and phytase (RONOZYME P-(CT) 100 ppm, DSM Nutritional products, Deinze, Belgium).

Table 1 here

Birds were housed in nine digestibility cages (three replicates per treatment), constructed with a wire bottom and a plastic tray for excreta collection, two feed troughs and a drinking cup. The facility was maintained under conventional EU conditions for lighting, heating and ventilation. The trial consisted of a pre-period of six days to minimise interference of egg yolk digestion (days 0 to 5) and a 48-hour collection period (days 5 to 7). Drinking water and feed were provided ad libitum. During the collection period, total excreta were collected, and pooled and homogeneous samples of the mixed wet excreta were freeze-dried and stored until analysis. The titanium dioxide content was determined using the method of Short et al. (1996) with modifications according to Myers et al. (2004). Samples of the feed and freeze-dried excreta were analysed in the accredited laboratory of the Institute for Agricultural and Fisheries Research (ILVO, Merelbeke, Belgium) for dry matter (DM), gross energy (GE), crude protein 
199 and crude fat according to EC (1971), ISO (1998, 9831), ISO $(2005,5983-2, \mathrm{~N} \times 6.25)$ and 200 ISO (1999, 6492), respectively. Additionally, the FA distribution of the ether extract of the 201 diets and excreta samples were determined (ISO, 2002, 17764).

202 The coefficient of total tract apparent digestibility (CTTAD) of DM, crude protein and crude 203 fat were determined by the use of the concentrations of titanium dioxide in the excreta and in 204 the feed, and calculated as described by Jansen et al. (2015). For the titanium dioxide in the 205 feed a single value, averaged over the diets, was used for all calculations. Average titanium 206 recovery was within acceptable limits for all diets. The coefficients of total tract apparent 207 digestibility of individual fatty acids (CTTADF) were calculated as follows:

$$
C T T A D F=\frac{\left[F A_{\text {diet }}-\left(F A_{\text {excreta }} \times(1-C T T A D \text { of crude fat })\right)\right]}{\left[F A_{\text {diet }}\right]}
$$

209 where $F A_{\text {diet }}$ and $F A_{\text {excreta }}$ are the respective FA contents $(\mathrm{g} / \mathrm{kg})$ analysed in the ether extract 210 of the diets and excreta samples. The AME contents of the experimental diets were calculated 211 from their respective titanium dioxide ratios and corresponding GE contents, as described by 212 Jansen et al. (2015).

213 The values for CTTAD of DM and crude fat, CTTADF, N-retention and AMEn were analysed 214 as a one factorial arrangement and subjected to ANOVA with STATGRAPHICS Centurion 215 XVI software (Statpoint Technologies Inc.). Repeated measures techniques were not used. 216 Means were separated by the least significant difference procedure. All statements of 217 significance were based on a P-value equal to or less than 0.05 .

\section{Experiment 3: Performance}

220 All experimental procedures were conducted in strict accordance with the European 221 Communities Council Directive (2003/65/EC) and were approved by the Ethics Committee of 222 Nottingham Trent University. 
223 Birds were sourced from PD Hook Cote hatchery, Oxford, UK. Birds were feather sexed on 224 day of hatch and collected by Nottingham Trent University (NTU) personnel to reduce travel stress. A total of 480-day-old male Ross 308 chicks were individually weighed before random allocation to $80 \times 80 \mathrm{~cm}$ mesh sided pens bedded on clean wood shavings. Unhealthy or unusually sized chicks were discarded from the trial upon arrival. Birds were individually weighed and only birds between 33 and $46 \mathrm{~g}$ were placed in trial cages.

Birds were allocated to four dietary treatments in a $2 \times 2$ factorial design. Treatments were; basal diet with soybean oil (2\%), basal diet with lecithin oil (2\%), basal diet with soybean oil with 250 ppm lysolecithin or basal diet with lecithin oil with 250 ppm lysolecithin. Compared to experiment 2, where dietary fat type and level were used to create challenging diets that could elucidate clearly the mode of action of lysolecithin, in experiment 3 the basal diets were formulated to reflect relevant commercial compositions and to meet all nutrient requirements of the birds (Table 2). The lecithin-based oil used in this study was commercially available as Leciol (Adams and Green, East Yorkshire, UK). The lysolecithin was supplemented as Lysoforte ${ }^{\circledR}$ Extend (Kemin Animal Nutrition and Health, Belgium). Each treatment consisted of 12 pens, with 10 birds per pen. Diets were manufactured by Target Feeds (Whitchurch, UK) and supplied bagged as mash for both starter and grower. Feed and water were available ad libitum, with care taken to ensure the birds ate and drank as soon as possible after placement. The lighting regimen was maintained in accordance with commercial practice with 15 minutes

242 of dusk at the start and end of each dark period. Temperature was set at $31^{\circ} \mathrm{C}$ on day 1 and 243 reduced by approximately $1^{\circ} \mathrm{C}$ per day until $21^{\circ} \mathrm{C}$ was reached.

Tazble 2 here 
247 Bird observations were used to monitor the environment and if the birds appeared 248 uncomfortable, the temperature and/or ventilation was altered accordingly. Birds were 249 observed twice daily during the trial and any observations related to health recorded in a trial 250 diary. Any dead birds were weighed, and reasons recorded if culled. Birds were weighed by 251 pen on arrival, on day 10 and at the end of the trial (day 21). Initially, individual weighed bags 252 of feed were prepared containing weighed feed quantities for each phase. Each pen of birds 253 was fed from their designated bag for each phase. Extra feed was added to the bags as required 254 and the quantity recorded. Total feed eaten was calculated as the difference between remaining 255 feed in the bag and the amount weighed into the bag for each phase.

256 Energy conversion efficiency ( $\mathrm{ME} \mathrm{MJ/kg} \mathrm{gain)} \mathrm{was} \mathrm{calculated} \mathrm{according} \mathrm{to} \mathrm{the} \mathrm{following}$ 257 formula, as per Salah et al. (2004):

Calorie conversion $=\frac{\text { Total Feed Consumption } \times \text { Energy content of feed }}{\text { Sum weight of all birds at trial end }}$

259 Calorie conversion was calculated using the calculated ME contents on the feed, using both on

260 the literature energy value of the two fat sources, as claimed by the manufacturers, and with 261 the energy value as determined by Wiseman et al. (1991).

262 Statistical analysis was carried out using SPSS v.24. After testing to confirm normality, data 263 were analysed using one-way ANOVA to investigate the effect of dietary treatment on FCR, 264 feed intake (per bird) and individual bodyweight gain for each weigh period of the study, and 265 cumulatively. Where appropriate, Bonferroni post hoc testing was used to elucidate differences 266 between diets/treatments.

\section{RESULTS}

269 Experiment 1: In vitro fat absorption

270 In experiment 1, palm oil contained a high amount of saturated FA ( $492.4 \mathrm{~g} / \mathrm{kg})$, especially 271 palmitic acid $(429.0 \mathrm{~g} / \mathrm{kg})$, which was largely reflected in the FA in the ether extract of the diet Accepted for publication 19 January 2020 
272 (Supplemental Table 1). The total lysophospholipid fraction was confirmed to be much higher 273 for soybean lysolecithin than for soybean lecithin $(118.8 \mathrm{~g} / \mathrm{kg}$ lysolecithin $v s .14 .1$ lecithin; 274 Supplemental Table 2). The majority of lysophospholipids in soybean lysolecithin were 275 lysophosphatidylcholine (LPC) and lysophosphatidyl-ethanolamine.

276 The hydrolysis of TG and the accumulation of FFA, DG and MG during the in vitro hydrolysis 277 of palm oil, palm oil with lecithin or with lysolecithin are shown in Figure 1. Over the whole 278 incubation period of $120 \mathrm{~min}$, the amounts of TG hydrolysed and FFA, DG and MG 279 accumulated in palm oil with lecithin are markedly lower than those of palm oil and palm oil 280 with lysolecithin. During the first 60 min of incubation, the amounts of TG hydrolysed and 281 FFA and MG accumulated were slightly higher in palm oil without lysolecithin or lecithin, 282 than in palm oil with lysolecithin. After $120 \mathrm{~min}$, however, the amounts of TG hydrolysed and 283 FFA and DG accumulated was slightly higher in palm oil with lysolecithin than in palm oil 284 without lysolecithin.

286 Fig 1 here

288 A comparison of the apparent first-order rate constants for TG hydrolysis and the accumulation of FFA, DG and MG for each treatment is presented in Table 3 Addition of lecithin or lysolecithin to the palm oil had significant $(\mathrm{P}<0.01)$ impact on the rates of TG hydrolysis and

291 FFA, DG and MG release. TG were hydrolysed faster when lysolecithin was added to the palm 292 oil $\left(\mathrm{k}=11.76 \times 10^{3} / \mathrm{min}\right)$ compared to palm oil without (lyso)lecithin $\left(\mathrm{k}=9.73 \times 10^{3} / \mathrm{min}\right)$. In contrast, TG were hydrolysed slower when lecithin was added $\left(\mathrm{k}=8.41 \times 10^{3} / \mathrm{min}\right)$. Similarly,

294 the release of MG was the fastest in palm oil with lysolecithin $\left(\mathrm{k}=3.07 \times 10^{3} / \mathrm{min}\right)$ and the 295 slowest in palm oil with lecithin $\left(\mathrm{k}=2.23 \times 10^{3} / \mathrm{min}\right)$. In contrast, DG release was the slowest 
296 in palm oil without lecithin or lysolecithin. There was no statistically significant difference 297 observed in the rate of free fatty acid release between palm oil and palm oil with lecithin.

Table 3 here

300

301 The absorption of MG and FFA generated during in vitro hydrolysis of palm oil, palm oil with 302 lecithin or with lysolecithin is presented in Figure 2. The absorption of MG was significantly 303 higher $(\mathrm{P}<0.01)$ for palm oil with lysolecithin $(85.6 \%)$ than for palm oil $(21.1 \%)$ or palm oil 304 with lecithin (35.5\%). The overall absorption of FFA was slightly lower $(\mathrm{P}>0.1)$ than that of 305 MG. Nevertheless, the absorption of FFA was significantly higher $(\mathrm{P}<0.01)$ for palm oil with 306 lysolecithin $(77.8 \%)$ than for palm oil alone (13.9\%) or with lecithin $(24.0 \%)$.

Fig 2 here

\section{Experiment 2: Digestibility}

311 In experiment 2, during the collection period the observed feed intake values were similar for 312 all treatments with an average of $30.6 \mathrm{~g}$ per bird per day. Likewise, bodyweight gain values were similar for all treatments with an average of $26.35 \mathrm{~g}$ per bird per day. Apparent faecal digestibility values and AMEn are presented in Table 4.

Table 4 here

There were significant differences $(\mathrm{P}<0.05)$ between the treatments for all parameters

319 investigated. Compared to the basal diet, lysolecithin supplementation increased $(\mathrm{P}<0.01)$ the DM digestibility by $1.04 \%$, CF digestibility by $2.25 \%$ and AMEn by $0.47 \mathrm{MJ} / \mathrm{kg}$. On the other 
321 hand, supplementation of lecithin had no effect on dry matter digestibility or AMEn, but

322

323

324

325

326

327

328

329

330

331

332

333

334

335

336

337

338

339

340

341

342

343

344

345 reduced $(\mathrm{P}<0.01)$ crude fat digestibility by $3.2 \%$. When compared to the basal diet, N-retention

was not significantly affected by lecithin or lysolecithin supplementation. However, Nretention of the basal diet supplemented with lysolecithin $(27.75 \mathrm{~g} / \mathrm{kg} \mathrm{DM})$ was higher $(\mathrm{P}<0.05)$ than that of the basal diet supplemented with lecithin $(25.26 \mathrm{~g} / \mathrm{kg} \mathrm{DM})$. Fatty acid distribution in the ether extracts of the faeces is presented in Table 5. There was no difference $(\mathrm{P}>0.05)$ between any of the dietary treatments in the fatty acid distribution in the faeces, nor in the ratio of unsaturated over saturated fatty acids.

Table 5 here

\section{Experiment 3: Performance Trial}

Table 6 shows the performance of the birds across the whole experimental period of experiment 3. During the starter phase, days $0-10$, there were no significant differences in average daily gain, feed intake or FCR between the treatment groups. However, birds fed the diet containing lecithin-based oil supplemented with lysolecithin were significantly heavier than those fed the diet with lecithin-based oil alone. During the grower phase there was a significant difference in bird weight. Birds fed the diet with lecithin-based oil alone were significantly lighter in weight when compared to the birds fed the diet with lecithin-based oil supplemented with lysolecithin $(\mathrm{P}=0.047)$. Similarly, when the whole trial phase was evaluated there were significant differences in average daily gain. Birds fed diets with lecithin-based oil alone gained less daily $(\mathrm{P}=0.036)$ than the birds fed the diet with lecithin-based oil supplemented with lysolecithin $(\mathrm{P}=0.036)$.

Table 6 here

Accepted for publication 19 January 2020 
347 The energetic values of each oil determined through analysis of chemical composition

348 (Supplemental Information Table 3) demonstrated that, due to high levels of FFA in the oils 349 and an altered unsaturated: saturated ratio (Wiseman et al., 1991), the lecithin oil had a reduced 350 predicted AME value for broilers $<21$ days compared to the soybean oil (36.57 MJ/kg soybean 351 vs. $32.64 \mathrm{MJ} / \mathrm{kg}$ lecithin). When calculating diet density based on lipid analysis, rather than 352 assuming energetic equivalence between the two oil sources, the effective energy conversion 353 rate for soybean oil alone was $16.04 \mathrm{MJ} / \mathrm{kg} \mathrm{BWG}$, while lecithin oil alone was worse, at 16.78 $354 \mathrm{MJ} / \mathrm{kg} \mathrm{BWG}$. With the addition of lysolecithin, the energy conversion rate was improved across 355 both fat sources (15.58 MJ/kg BWG soybean oil + lysolecithin; $16.23 \mathrm{MJ} / \mathrm{kg} \mathrm{BWG}$ lecithin 356 plus lysolecithin); the effective efficiency of use of the lecithin oil was brought closer to that 357 of unsupplemented soya oil.

\section{DISCUSSION}

360 The structural differences in the composition of lecithin and lysolecithin leads to fundamentally 361 diverse effects on both in vitro and in vivo lipid digestion. In experiment 1, compared to palm 362 oil without lecithin or lysolecithin, the apparent rate constants in vitro for triglyceride hydrolysis and monoglyceride release were significantly higher for palm oil supplemented with

364 lysolecithin and significantly lower for palm oil supplemented with soybean lecithin (Figures

3651 and 2). Likewise, in experiment 2, compared to the basal diet, crude fat digestibility was 366 significantly higher in broilers supplemented with lysolecithin, but was significantly lower in 367 broilers supplemented with lecithin. Though the limitations of this initial study require further 368 data to confirm these findings, Zhang et al. (2011) postulated that, while both lecithin and 369 lysolecithin may act as an emulsifier within the first stages of lipid digestion, for hydrolysis to 370 take place, the pancreatic colipase-lipase complex first must be adsorbed onto the emulsion 
371 droplets (Reis et al., 2010). The adsorption and activity of lipase at the oil-water interface,

372 however, is affected by various surface-active compounds such as phospholipids and

373 lysophospholipids (Reis et al., 2010; 2009).

374 Possibly the observed effect of lecithin on crude fat digestion in young broilers in experiment

3752 could be explained by a study of Chu et al. (2010), who showed that colipase and lipase

376 adsorbed exclusively onto regions covered by phosphatidylcholine and bile salts and not to

377 regions covered with phosphatidylcholine solely. This suggested that, although phospholipids

378 in lecithin may have aided in the formation of smaller emulsion droplets, the young broiler

379 produces insufficient bile salts. This is especially the case in diets containing high levels of

380 palm oil where, due to the low amount of unsaturated fatty acids, digestibility is more

381 challenging than with other, more unsaturated, vegetable oils, such as soybean oil

382 (Tancharoenrat et al., 2013) to facilitate the adsorption of the colipase-lipase complex to the

383 surface of the droplet. The combination of the challenging basal fat type (palm oil) and level

384 with the immature digestive system in young broilers led to a relatively low crude fat

385 digestibility in the basal diet $(69.52 \%)$ seen in experiment 2 . It is well known that relative

386 digestibility coefficients of fat are limited when fats and oils are present at a high levels (Croom

387 et al., 1999; Rampone, 1961), as the ability of the digestive system and liver for lipolysis and

388 absorption become rate limiting. However, in contrast to the phospholipids contained in

389 lecithin, it has been suggested that, once in the small intestine, lysophospholipids tend to

390 dissolve into mixed micelles and, in this way, leave the interface (Nik et al., 2010). Moreover,

391 through their participation in the formation of mixed micelles, lysophospholipids may play an

392 additional role by displacing MG and FFA from the interface, allowing lipid hydrolysis to

393 continue (Lairon, 2009). Recent studies have demonstrated the effect of lysolecithin on the

394 intestinal mucosa. Papadopoulos et al. (2018) reported significantly thinner mucosa in birds

395 supplemented with lysolecithin than in unsupplemented birds, while Chen et al. (2019) 
396 reported elevated claudin-3 levels following lysolecithin supplementation, indicating better 397 sealing of tight junctions (Milatz et al., 2010). Brautigan et al. (2017) showed increased 398 collagen deposition and villus height following lysolecithin supplementation. Together, these 399 results suggested that, as lysolecithin becomes incorporated into the epithelial cell walls, it 400 improves mucosal absorptive capacity in a way lecithin cannot.

401 Although in this 'proof of concept' study lecithin had a negative effect on lipid hydrolysis, no 402 adverse effect was observed on the absorption of generated MG and FFA by the differentiated 403 Caco-2 monolayer (Figure 2). This supported the argument that phospholipids likely reside at 404 the interface of emulsion droplets and do not participate in the absorption process in 405 enterocytes. In contrast, the absorption of MG and FFA was higher with digests from the palm 406 oil supplemented with lysolecithin than with digests from palm oil and palm oil supplemented 407 with lecithin. Similarly, in a study by Sugawara et al. (2001) the uptake of lipid-soluble 408 carotenoids was greatly improved in Caco-2 cells exposed to micelles containing 409 lysophosphatidylcholine in comparison to cells incubated with micelles containing 410 phosphatidylcholine.

411 In addition to the improved CF digestibility and DM digestibility, AMEn of the basal diet 412 supplemented with lysolecithin was significantly higher than that of the basal diet or basal diet 413 supplemented with lecithin. This is in line with previous studies, which have shown 414 improvements in $\mathrm{CF}$ and $\mathrm{N}$ digestibility following lysolecithin supplementation, although the 415 effect of fat source on response is still uncertain: Zaefarian et al. (2015) reported improved 416 AMEn values in supplemented soy oil diets, but little effect of lysolecithin on diets formulated 417 with tallow. Conversely, Jansen et al. (2015) reported improvements in AMEn of diets 418 formulated with pig lard but not those formulated with soybean oil. Across 33 studies, 419 Wealleans et al. (2019) found little evidence that the magnitude of response to lysolecithin 420 supplementation was consistently altered by dietary fat type. In the present study, N-retention 
421 for the basal diet supplemented with lysolecithin was significantly higher than in the basal diet supplemented with lecithin. Furthermore, the AMEn improvement of $0.47 \mathrm{MJ} / \mathrm{kg}$ by lysolecithin supplementation was only partially attributed to the $2.25 \%$ improvement in CF digestibility.

Honda et al. (2009) found that fats incorporated in the feed matrix could encapsulate other nutrients, lowering their digestion. As a consequence of improved CF digestibility, lysolecithins could, in this way, enhance the digestion of other nutrients. Another possible explanation for the large improvement in AMEn may be found at the enterocyte level. As supported by the improved absorption of MG and FFA in the present study, lysolecithin may enhance the uptake of multiple nutrients across the enterocyte membrane. Lysophospholipids are known to alter membrane structure by inducing local curvatures in the bilayer (Lundbaek, 2006; Wendel, 2000; Maingret et al., 2000). Moreover, they can affect proteins embedded in the membrane (Lundbaek, 2006; Maingret et al., 2000; Lundbaek and Andersen, 1994). In this way lysophospholipids could enhance the uptake of nutrients across the membrane of the microvilli in the intestinal epithelium, which is supported by the work of Brautigan et al. (2017), who reported increased villus height and collagen cross-linkages, driven by upregulation of collagen-related genes in the intestinal epithelium of broilers supplemented with lysolecithin.

These differential effects on fat hydrolysis and overall digestibility between lecithin and

440 lysolecithin were supported by the performance results of experiment 3, although the basal diet 441 formulations were substantially different, and designed to be more commercially relevant, from 442 those used in experiment 2 Substituting soya oil for lecithin oil at the same concentration 443 numerically reduced broiler growth and increased FCR until day 10 of age (1.45 soya oil vs. 4441.55 lecithin oil, $\mathrm{P}=0.161$ ), while weight at day 10 was $3 \%$ lower in birds fed the lecithin oil 445 diet compared to those formulated with soya oil. Although differences between 
446 unsupplemented soya and lecithin oil treatments were not statistically significant, the large 447 difference in FCR during the starter phase was commercially important to overall production 448 profitability. Similarly, Huang et al. (2007) reported that complete replacement of the soybean 449 oil with lecithin ( $2 \%$ lecithin in the diet) resulted in adverse effects. This was greatest in young 450 birds, and, after day 10, the gap in feed conversion ratio between soya oil and lecithin oil diets narrowed (6.9\% increase in FCR lecithin vs. soya to day 10, 3.1\% increase in FCR lecithin vs. soya day 10-21), with birds on all treatments performing similarly. Until 14 days of age, fat digestion was severely limited in chicks due to a lack of bile salt secretion (Krogdahl, 1985), after which the rates of synthesis increased fourfold. Therefore, it was likely that birds fed the lower available energy diets containing lecithin oil were able to achieve compensatory growth once bile salt synthesis reached sufficient levels and fat digestion improved (Krogdahl, 1985), thus closing the performance gap with those fed diets containing soya oil, despite energy conversion efficiency rates remaining lower throughout the trial.

Future research on the comparative effects of lecithin and lysolecithin should continue to assess the effect on performance and digestibility until slaughter, when the bird is physiologically more mature. Meanwhile, the performance increases seen with supplemental lysolecithin were in line with previous research, which demonstrated improved weight gain and FCR (Wealleans et al., 2019; Allahyari-Bake and Jahanian, 2017; Zaefarian et al., 2015; Zampiga et al., 2016), while others have reported increases in AME (Majdolhosseini et al., 2019; Melegy et al., 2010;

465 Jansen et al., 2015).

466 To conclude, this study presented evidence that lysolecithins, but likely not lecithin itself, are 467 able to significantly improve the digestibility and energy values of feed, especially in young broilers. These improvements may be due to a combined effect of lysophospholipids on lipid hydrolysis and nutrient absorption, although further research is required to confirm any multifactorial mode of action 


\section{ACKNOWLEDGEMENT}

473 The authors wish to acknowledge the Institute for the Promotion of Innovation through Science 474 and Technology in Flanders (Project Number 110534, Brussels, Belgium) for financial support 475 for Experiments 1 and 2 of this paper.

476

477

\section{REFERENCES}

Allahyari-Bake, S., and R. Jahanian. 2016. "Effects of dietary fat source and supplemental lysophosphatidylcholine on performance, immune responses, and ileal nutrient digestibility in 480 broilers fed corn/soybean meal-or corn/wheat/soybean meal-based diets." Poultry Science 96 : $481 \quad 1149-1158$.

482 Blanch, A., A. C. Barroeta, M. D. Baucells, X. Serrano, and F. Puchal. 1996. "Utilisation of 483 different fats and oils by adult chickens as a source of energy, lipid and fatty acids". Animal $484 \quad$ Feed Science and Technology. 61:335-342.

485 Brautigan, D.L., R. Li, E. Kubicka, S.D. Turner, J.S. Garcia, M.L. Weintraut and E.A. Wong. 486 2017. "Lysolecithin as feed additive enhances collagen expression and villus length in the 487 jejunum of broiler chickens.” Poultry Science, p.pex078.

488 Chen, C., B. Jung and W.K. Kim. 2019. "Effects of lysophospholipid on growth performance, 489 carcass yield, intestinal development, and bone quality in broilers.” Poultry Science. 98: 39024903913.

491 Chu, B.S., A. P. Gunning, G. T. Rich, M. J. Ridout, R. M. Faulks, M. S. J. Wickham, and P. J. 492 Wilde. 2010. "Adsorption of bile salts and pancreatic colipase and lipase onto 493 digalactosyldiacylglycerol and dipalmitoylphosphatidylcholine monolayers". Langmuir 26: $4949782-9793$. 
495 Croom, W.J., J. Brake, B.A. Coles, G.B Havenstein, V.L. Christensen, B.W. McBride, E.D. 496 Peebles and I.L. Taylor. 1999. "Is intestinal absorption capacity rate-limiting for performance 497 in poultry?” Journal of Applied Poultry Research. 8: 242-252.

498 Huang, J., D. Yang, and T. Wang. 2007. "Effects of replacing soy-oil with soy-lecithin on 499 growth performance, nutrient utilisation and serum parameters of broilers fed corn-based 500 diets". Asian-Australasian Journal of Animal Science. 20:1880-1886.

501 Honda, K., H. Kamisoyama, Y. Isshiki, and S. Hasegawa. 2009. "Effects of dietary fat levels 502 on nutrient digestibility at different sites of chicken intestines”. Journal of Poultry Science. $503 \quad 46: 291-295$.

504 Huang, J., D. Yang, S. Gao, and T. Wang. 2008. "Effects of soy lecithin on lipid metabolism 505 and hepatic expression of lipogenic genes in broiler chickens". Livestock Science. 118:53-60. 506 Jansen, M., F. Nuyens, J. Buyse, S. Leleu, and L. Van Campenhout. 2015. "Interaction between 507 fat type and lysolecithin supplementation in broiler feeds." Poultry Science 94: 2506-2515.

508 Joshi, A., S. G. Paratkar, and B. N. Thorat. 2006. "Modification of lecithin by physical, 387 509 chemical and enzymatic methods”. European Journal of Lipid Science and Technology. $510 \quad 108: 363-373$

511 Karray, A., Zarai, Z., Gargouri, Y., Verger, R., and S. Bezzine. 2011.” Kinetic properties of 512 pancreatic and intestinal sPLA2 from chicken and mammals using the monomolecular film 513 technique”. Journal of Colloid and Interface Science. 363:620-625.

514 Krogdahl, A. 1985. "Digestion and absorption of lipids in poultry". Journal of Nutrition 515 115:675-685.

516 Lairon, D. 2009. Digestion and absorption of lipids. Pages 68-93 in Designing Functional 517 Foods, ed. J. McClements and E. Decker. Sawston, Cambridge. 
518 Liu. D., and F. Ma. 2011. Soybean phospholipids. Pages 483-500 in Recent trends for

519 enhancing the diversity and quality of soybean products, ed. D. Krezhova. Intech, Rijeka, 520 Croatia.

521 Lo, C. M., and P. Tso. 2009. Physicochemical basis of the digestion and absorption of 522 triacylglycerol. Pages 94-125 in Designing functional foods, ed. J. McClements and E. Decker. 523 Sawston, Cambridge.

524 Lundbaek, J. A. 2006. "Regulation of membrane protein function by lipid bilayer elasticity: a 525 single molecule technology to measure the bilayer properties experienced by an embedded 526 protein”. Journal of Physics: Condensed Matter. 18:1305-1344

527 Lundbaek, J. A., and O. S. Andersen. 1994. "Lysophospholipids modulate channel function by 528 altering the mechanical properties of lipid bilayers". Journal of General Physiology. 104:64552973.

530 Maingret, F., A. J. Patel, F. Lesage, M. Lazdunski, and E. Honoré. 2000. "Lysophospholipids 531 open the two-pore domain mechano-gated $\mathrm{K}(+)$ channels TREK-1 and TRAAK”. Journal of 532 Biological Chemistry. 275:10128-10133.

533 Maiorka, A., A. V. F. Da Silva, E. Santin, J. M. Pizauro, and M. Macari. 2004. "Broiler Breeder 534 Age and Dietary Energy Level on Performance and Pancreas Lipase and Trypsin Activities of 535 7-days Old Chicks”. International Journal of Poultry Science. 3:234-237.

536 Maisonnier, S., J. Gomez, A. Brée, C. Berri, E. Baéza and B. Carré. 2003. "Effects of 537 microflora status, dietary bile salts and guar gum on lipid digestibility, intestinal bile salts, and 538 histomorphology in broiler chickens.” Poultry Science 82: 805-814.

539 Majdolhosseini, L., H.A. Ghasemi, I. Hajkhodadadi and M.H. Moradi. 2019. "Nutritional and 540 physiological responses of broiler chickens to dietary supplementation with de-oiled soyabean 541 lecithin at different metabolisable energy levels and various fat sources." British Journal of $542 \quad$ Nutrition 122: 863-872. 
543 Melegy T., N.F. Khaled, R. El-Bana, and H. Abdellatif. 2010. "Dietary fortification of a natural

544 biosurfactant, lysolecithin in broilers." African Journal of Agricultural Research 5: 28865452892.

546 Meng, X., B. A. Slominski, and W. Guenter 2004. "The effect of fat type, carbohydrase, and 547 lipase addition on growth performance and nutrient utilisation of young broilers fed wheat548 based diets”. Poultry Science. 83:1718-1727.

549 Milatz, S., S.M. Krug, R. Rosenthal, D. Günzel, D. Müller, J.D. Schulzke, S. Amasheh and M. 550 Fromm. 2010. „Claudin-3 acts as a sealing component of the tight junction for ions of either 551 charge and uncharged solutes." Biochimica et Biophysica Acta (BBA)-Biomembranes, 1798: $552 \quad 2048-2057$.

553 Myers, W.D., P.A. Ludden, V. Nayigihugu and B.W. Hess. 2004. "Technical note: a procedure 554 for the preparation and quantitative analysis of samples for titanium dioxide." Journal of 555 Animal Science 82:179-183.

556 Nik, A.M., A.J. Wright and M. Corredig. 2010. "Interfacial design of protein-stabilized 557 emulsions for optimal delivery of nutrients". Food Functions 1: 141-148.

558 Papadopoulos, G.A., T. Poutahidis, S. Chalvatzi, M. Di Benedetto, A. Hardas, V. Tsiouris, I 559 Georgopoulou, G. Arsenos and P.D. Fortomaris. 2018. "Effects of lysolecithin 560 supplementation in low-energy diets on growth performance, nutrient digestibility, viscosity 561 and intestinal morphology of broilers.” British Poultry Science. 59: 232-239.

562 Papadopoulos, G.A., K. Müller, D. Schertling and M. Di Benedetto. 2014. "Supplementation 563 of lysolecithin in combination with a multi-non-starch polysaccharides enzyme improves the 564 feed efficiency during the post-weaning period in piglets". Acta Agriculturae Scandinavica, 565 Section A-Animal Science. 64(2):130-136.

566 Polin, D., T. L. Wing, P. Ki, and K. E. Pell. 1980. "The effect of bile acids and lipase on 567 absorption of tallow in young chicks”. Poultry Science. 59:2738-2743. 
568 Rampone, A.J. 1961. "Rate of Fat Uptake by Intestinal Lymphatics." Proceedings of the 569 Society for Experimental Biology and Medicine. 108: 278-282.

570 Raju, M. V. L. N., S. V. R. Rao, P. P. Chakrabarti, B. V. S. K. Rao, A. K. Panda, B. L. A. P.

571 Devi, V. Sujatha, J. R. C. Reddy, G. Shyam Sunder, and R. B. N. Prasad. 2011. "Rice bran 572 lysolecithin as a source of energy in broiler chicken diet". British Poultry Science. 52:769-774.

573 Ravindran, V., P. Tancharoenrat, F. Zaefarian, and G. Ravindran. 2016. "Fats in poultry 574 nutrition: Digestive physiology and factors influencing their utilisation." Animal Feed Science 575 and Technology 213: 1-21.

576 Reis, P., K. Holmberg, H. Watzke, M. E. Leser, and R. Miller. 2009. "Lipases at interfaces: a 577 review". Advanced Colloid Interface Science. 147: 237-250.

578 Reis, P., H. Watzke, M. Leser, K. Holmberg, and R. Miller. 2010. "Interfacial mechanism of 579 lipolysis as self-regulated process”. Biophysical Chemistry. 147: 93-103.

580 Roy, A., S. Haldar, S. Mondal, and T. K. Ghosh. 2010. "Effects of supplemental exogenous 581 emulsifier on performance, nutrient metabolism, and serum lipid profile in broiler chickens". 582 Veterinary Medicine International. doi:10.4061/2010/262604.

583 Saleh, E. A., S. E. Watkins, A. L. Waldroup, and P. W. Waldroup. 2004. "Effects of dietary 584 nutrient density on performance and carcass quality of male broilers grown for further 585 processing.” International Journal Poultry Science 3: 1-10.

586 Short, F. J., P. Gorton, J. Wiseman and K.N. Boorman. 1996. "Determination of titanium 587 dioxide added as an inert marker in chicken digestibility studies." Animal Feed Science and 588 Technology 59:215-221.

589 Sugawara, T., M. Kushiro, H. Zhang, and E. Nara. 2001. "Nutrient Interactions and Toxicity 590 Lysophosphatidylcholine Enhances Carotenoid Uptake from Mixed Micelles by Caco-2 591 Human Intestinal Cells”. Journal of Nutrition. 131:2921-2927. 
592 Tancharoenrat, P., V. Ravindran, F. Zaefarian, and G. Ravindran. 2013. "Influence of age on 593 the apparent metabolisable energy and total tract apparent fat digestibility of different fat 594 sources for broiler chickens”. Animal Feed Science and Technology. 186:186-192.

595 Van Nieuwenhuyzen, W., and M. C. Tomás. 2008. "Update on vegetable lecithin and 596 phospholipid technologies”. European Journal of Lipid Science and Technology. 110:472-486.

597 Vors, C., P. Capolino, C. Guérin, E. Meugnier, S. Pesenti, M. A. Chauvin, J. Monteil, N. 598 Peretti, M. Cansell, F. Carrière, and M. C. Michalski. 2012. "Coupling in vitro gastrointestinal 599 lipolysis and Caco-2 cell cultures for testing the absorption of different food emulsions". Food $600 \quad$ Functions. 3:537-46

601 Wang, Q.Q., S.F. Long, J.X. Hu, M. Li, L. Pan, and X.S Piao. 2019. "Effects of dietary 602 lysophospholipid complex supplementation on lactation performance, and nutrient digestibility 603 in lactating sows". Animal Feed Science and Technology. 251:56-63

604 Wealleans, A.L; Jansen, M and di Benedetto, M., 2019. "Addition of lysolecithin to broiler 605 diets improves growth performance across fat levels and sources". British Poultry Science. In 606 Press.

607 Wendel, A. 2000. Lecithin. Pages 1-19 in Kirk-Othmer Encyclopedia of Chemical Technology. 608 Ed. John Wiley \& Sons, Inc., New York.

609 Wiseman, J., F. Salvador, and J. Craigon. 1991. "Prediction of the apparent metabolizable 610 energy content of fats fed to broiler chickens." Poultry Science 70(7): 1527-1533.

611 Zaefarian, F., L.F. Romero, and V. Ravindran. 2015. "Influence of high dose of phytase and 612 an emulsifier on performance, apparent metabolisable energy and nitrogen retention in broilers 613 fed on diets containing soy oil or tallow.” British Poultry Science 56: 590-597.

614 Zampiga, M., A. Meluzzi, and F. Sirri. 2016. "Effect of dietary supplementation of 615 lysophospholipids on productive performance, nutrient digestibility and carcass quality traits 616 of broiler chickens.” Italian Journal of Animal Science 15: 521-528. 
617 Zhang, B., L. Haitao, D. Zhao, Y. Guo, and A. Barri. 2011. "Effect of fat type and

618 lysophosphatidylcholine addition to broiler diets on performance, apparent digestibility of fatty

619 acids, and apparent metabolizable energy content." Animal Feed Science and Technology 163:

$620 \quad 177-184$.

621 Zhao, P.Y., Z.F. Zhang, R.X. Lan, W.C. Liu and I.H Kim. 2017. "Effect of lysophospholipids

622 in diets differing in fat contents on growth performance, nutrient digestibility, milk

623 composition and litter performance of lactating sows”. animal, 11: 984-990.

624 
625 Table 3. Effect of soybean lecithin and soybean lysolecithin on the apparent first-order rate

626 constant $\left(\mathrm{k} \times 10^{3} / \mathrm{min}\right)$ of triglyceride hydrolysis and diglyceride, monoglyceride and free fatty

627 acid release during in vitro digestion of palm oil (Experiment 1)

\begin{tabular}{|c|c|c|c|c|}
\hline & $\begin{array}{l}\text { Triglyceride } \\
\text { hydrolysis }\end{array}$ & $\begin{array}{l}\text { Diglyceride } \\
\text { release }\end{array}$ & $\begin{array}{l}\text { Monoglyceride } \\
\text { release }\end{array}$ & $\begin{array}{l}\text { Free fatty acid } \\
\text { release }\end{array}$ \\
\hline \multicolumn{5}{|l|}{ Treatment $^{1}$} \\
\hline Palm oil & $9.73^{b}$ & $1.15^{\mathrm{c}}$ & $2.91^{\mathrm{b}}$ & $10.85^{b}$ \\
\hline Palm oil + lecithin ${ }^{2}$ & $8.41^{\mathrm{c}}$ & $1.58^{\mathrm{b}}$ & $2.23^{\mathrm{c}}$ & $9.49^{\mathrm{b}}$ \\
\hline Palm oil + lysolecithin 3 & $11.67^{\mathrm{a}}$ & $1.70^{\mathrm{a}}$ & $3.07^{\mathrm{a}}$ & $12.49^{\mathrm{a}}$ \\
\hline Pooled SEM & 0.28 & 0.02 & 0.04 & 0.45 \\
\hline$P$-value & 0.001 & 0.000 & 0.000 & 0.009 \\
\hline
\end{tabular}

$628{ }^{a-c}$ Values within columns with different superscripts are significantly different $(\mathrm{P}<0.05)$.

$629{ }^{1}$ Data are means of three observations per treatment.

$630 \quad 2,3$ Lecithin and lysolecithin were applied at $1 \mathrm{~g}$, dispersed into $49 \mathrm{~g}$ of oil 
632 Table 1. Ingredients and nutrient composition of the basal ${ }^{1}$ experimental diet (Experiment 2)

\begin{tabular}{lc}
\hline Item $(\mathrm{g} / \mathrm{kg}$, unless noted) & Starter diet \\
\hline Ingredient & 452.9 \\
Corn & 100.0 \\
Wheat & 363.2 \\
Soybean meal $(45.3 \% \mathrm{CP})$ & 40.0 \\
Palm oil & 13.6 \\
Monocalcium phosphate & 10.0 \\
Vitamin and mineral premix ${ }^{2}$ & 3.0 \\
Methionine & 2.3 \\
Lysine HCl & 0.6 \\
Threonine & 6.8 \\
Limestone & 2.0 \\
NaCl & 2.5 \\
NaHCO & 3.0 \\
TiO & \\
& \\
Calculated composition & \\
AMEn (MJl/kg) & 11.41 \\
Crude fibre & 3.19 \\
Lysine & 1.15 \\
Methionine + cysteine & 0.86 \\
Threonine & 0.75 \\
Calcium & 0.85 \\
Total phosphorus & 0.69 \\
Available phosphorus & 0.40 \\
Sodium & 0.15 \\
Analysed composition & \\
Dry matter & 90.43 \\
Crude protein & 23.05 \\
Crude fat & 7.25 \\
TiO & \\
Gross energy $(\mathrm{MJ} / \mathrm{kg})$ & 17.50 \\
\hline
\end{tabular}

$633{ }^{1}$ For experimental treatments, lysolecithin was added on top of the specified basal diet at 250 $634 \mathrm{ppm}$

$635{ }^{2}$ Supplied per kilogram of diet: manganese, $99 \mathrm{mg}$; zinc, $60 \mathrm{mg}$; iron, $49 \mathrm{mg}$; copper, $20 \mathrm{mg}$; 636 iodine, $1.2 \mathrm{mg}$; selenium, $0.4 \mathrm{~g}$; vitamin A, 13,500 IU (retinyl acetate); vitamin E, $55 \mathrm{IU}$ 637 (DL- $\alpha$-tocopheryl acetate); cholecalciferol, $75 \mu \mathrm{g}$; vitamin $\mathrm{B}_{1}, 2 \mathrm{mg}$; vitamin $\mathrm{B}_{2}, 5 \mathrm{mg}$; 638 vitamin $\mathrm{B}_{3}, 30 \mathrm{mg}$; vitamin $\mathrm{B}_{5}, 15 \mathrm{mg}$; vitamin $\mathrm{B}_{6}, 4 \mathrm{mg}$; vitamin $\mathrm{B}_{12}, 2 \mathrm{mg}$; vitamin $\mathrm{K}, 2.5$ $639 \mathrm{mg}$; folic acid, $1 \mathrm{mg}$; biotin; $0.2 \mathrm{mg}$; choline, $600 \mathrm{mg}$; etoxyquine, $33 \mathrm{mg}$; butylated 640 hydroxytoluene (BHT), $0.4 \mathrm{mg}$; propyl gallate, $0.12 \mathrm{mg}$; citric acid, $0.69 \mathrm{mg}$; sepiolite, $4 \mathrm{mg}$. $641{ }^{3}$ Values represent the mean of the three experimental diets. 
644 Table 4. Effect of soybean lecithin and soybean lysolecithin on the apparent faecal dry matter 645 and crude fat digestibility, nitrogen retention and AMEn of young broilers fed a palm oil rich $646 \operatorname{diet}($ Experiment 2)

\begin{tabular}{|c|c|c|c|c|}
\hline & \multicolumn{2}{|c|}{ Digestibility $(\%)$} & \multirow{2}{*}{$\begin{array}{l}\text { N-retention } \\
\text { (g/kg DM) }\end{array}$} & \multirow{2}{*}{$\begin{array}{l}\text { AMEn } \\
(\mathrm{MJ} / \mathrm{kg} \mathrm{DM})\end{array}$} \\
\hline & DM & Crude fat & & \\
\hline \multicolumn{5}{|l|}{ Dietary treatment ${ }^{1}$} \\
\hline Basal diet & $69.85^{b}$ & $69.52^{b}$ & $27.03^{\mathrm{ab}}$ & $13.03^{b}$ \\
\hline Basal diet + lecithin & $69.47^{b}$ & $66.32^{\mathrm{c}}$ & $25.26^{\mathrm{b}}$ & $13.03^{b}$ \\
\hline Basal diet + lysolecithin & $72.88^{\mathrm{a}}$ & $71.77^{\mathrm{a}}$ & $27.75^{\mathrm{a}}$ & $13.50^{\mathrm{a}}$ \\
\hline Pooled SEM & 0.16 & 0.71 & 0.53 & 0.16 \\
\hline$P$-value & 0.000 & 0.003 & 0.039 & 0.008 \\
\hline
\end{tabular}


650 Table 5. Fatty acid distribution (\%) in the ether extracts of the faeces of young broilers fed a

651 basal palm oil diet, the basal diet supplemented with lecithin and the basal diet supplemented

652 with lysolecithin (Experiment 2)

\begin{tabular}{lccccc}
\hline \hline Fatty acid & Basal diet & $\begin{array}{c}\text { Basal diet } \\
+ \text { lecithin }\end{array}$ & $\begin{array}{c}\text { Basal Diet } \\
+ \text { lysolecithin }\end{array}$ & $\begin{array}{c}\text { Pooled } \\
\text { SEM }\end{array}$ & $P$-value \\
\hline C16:0 & 40.59 & 40.47 & 41.23 & 0.69 & $\mathrm{NS}$ \\
C18:0 & 6.29 & 6.89 & 6.91 & 0.15 & $\mathrm{NS}$ \\
C18:1 $(\omega-9)$ & 23.71 & 23.47 & 23.75 & 0.12 & $\mathrm{NS}$ \\
C18:2 $(\omega-6)$ & 26.01 & 26.46 & 25.55 & 0.75 & $\mathrm{NS}$ \\
C18:3 $(\omega-3)$ & 0.69 & 0.71 & 0.65 & 0.02 & $\mathrm{NS}$ \\
Total unsaturated fatty acids & 49.34 & 49.13 & 49.83 & 0.84 & $\mathrm{NS}$ \\
Total saturated fatty acids & 50.66 & 50.87 & 50.17 & 0.84 & $\mathrm{NS}$ \\
Ratio unsaturated / saturated & 1.03 & 1.04 & 1.01 & 0.03 & $\mathrm{NS}$ \\
\hline
\end{tabular}

$653{ }^{1}$ Fatty acids that are not listed were present for less than $0.5 \%$ in all samples.

6542 Data are means of three observations per treatment. 
655 Table 2. Ingredients and nutrient composition of the basal experimental $\operatorname{diets}^{1}$ (Experiment 3)

\begin{tabular}{lcc}
\hline \hline Item $(\mathrm{g} / \mathrm{kg}$, unless noted) & Soybean Oil & Lecithin Oil \\
\hline Wheat & 541.6 & 541.6 \\
Pura $^{2}$ & 100.0 & 100.0 \\
Soybean Meal (46.6\% CP) & 304.0 & 304.0 \\
Soybean Oil & 20.0 & -- \\
Lecithin Oil & -- & 20.0 \\
Limestone & 5.6 & 5.6 \\
Salt & 1.6 & 1.6 \\
Sodium Bicarbonate & 2.8 & 2.8 \\
DCP & 12.4 & 12.4 \\
Lysine HCl & 2.7 & 2.7 \\
DL Methionine & 3.4 & 3.4 \\
Threonine & 1.0 & 1.0 \\
Ronozyme P5000 & 0.15 & 0.15 \\
Ronzyme WX & 0.15 & 0.15 \\
Vit/Min Premix & 3.63 & 4.63
\end{tabular}

Calculated composition, $\%$

$\mathrm{ME}, \mathrm{MJ} / \mathrm{kg}$

$12.609 \mathrm{MJ} / \mathrm{kg}$

Crude Protein

22.47

Crude Fat

6.207

Crude Fibre

3.38

Dig Lys

1.247

Dig Met

0.623

Dig Met+Cys

0.938

$\mathrm{Ca}$

0.898

Av $\mathrm{P}$

0.449

$\mathrm{Na}$

0.150

$656{ }^{1}$ Lysolecithins (as LYSOFORTE ${ }^{\circledR}$ EXTEND) were added on top of the basal diet formulations 657 at $500 \mathrm{ppm}$

6582 Pura is a commercially available blend of whole rapeseed and pulses (field beans or peas)

659 which has been ground, heat treated and pelleted. Typical analysis $21 \%$ oil, $21 \%$ protein.

660 3Supplied per kilogram of diet: manganese, $99 \mathrm{mg}$; zinc, $60 \mathrm{mg}$; iron, $49 \mathrm{mg}$; copper, $20 \mathrm{mg}$;

661 iodine, $1.2 \mathrm{mg}$; selenium, $0.4 \mathrm{~g}$; vitamin A, 13,500 IU (retinyl acetate); vitamin E, $55 \mathrm{IU}$

662 (DL- $\alpha$-tocopheryl acetate); cholecalciferol, $75 \mu \mathrm{g}$; vitamin $\mathrm{B}_{1}, 2 \mathrm{mg}$; vitamin $\mathrm{B}_{2}, 5 \mathrm{mg}$;

663 vitamin $\mathrm{B}_{3}, 30 \mathrm{mg}$; vitamin $\mathrm{B}_{5}, 15 \mathrm{mg}$; vitamin $\mathrm{B}_{6}, 4 \mathrm{mg}$; vitamin $\mathrm{B}_{12}, 2 \mathrm{mg}$; vitamin $\mathrm{K}, 2.5$

$664 \mathrm{mg}$; folic acid, $1 \mathrm{mg}$; biotin; $0.2 \mathrm{mg}$; choline, $600 \mathrm{mg}$; etoxyquine, $33 \mathrm{mg}$; butylated

665 hydroxytoluene (BHT), $0.4 \mathrm{mg}$; propyl gallate, $0.12 \mathrm{mg}$; citric acid, $0.69 \mathrm{mg}$; sepiolite, $4 \mathrm{mg}$. 
666 Table 6. Growth performance of young broilers from day 0-21 fed diets formulated with soya oil or lecithin oil, with or without supplemental

667 lysolecithin. (Experiment 3).

\begin{tabular}{|c|c|c|c|c|c|c|}
\hline & Soya Oil & $\begin{array}{c}\text { Soya Oil } \\
+ \text { Lysolecithin } \\
\end{array}$ & Lecithin Oil & $\begin{array}{c}\text { Lecithin Oil } \\
+ \text { Lysolecithin }\end{array}$ & $\begin{array}{l}\text { Pooled } \\
\text { SEM }\end{array}$ & P-value \\
\hline \multicolumn{7}{|l|}{ Day 0-10 1} \\
\hline Weight at day $0, \mathrm{~g}$ & 38.3 & 38.3 & 38.6 & 38.9 & 0.72 & 0.906 \\
\hline Average daily gain, g & 21.2 & 21.5 & 20.8 & 22.0 & 0.41 & 0.198 \\
\hline Average daily feed intake, $g$ & 32.0 & 29.5 & 32.3 & 31.6 & 1.13 & 0.326 \\
\hline FCR & 1.45 & 1.36 & 1.55 & 1.43 & 0.060 & 0.161 \\
\hline \multicolumn{7}{|l|}{ Day 10-21 } \\
\hline Weight at day $10, \mathrm{~g}$ & $256.2^{\mathrm{ab}}$ & $258.9^{\mathrm{ab}}$ & $248.9^{b}$ & $263.8^{\mathrm{a}}$ & 3.18 & 0.015 \\
\hline Average daily gain, $g$ & 61.3 & 61.4 & 59.4 & 63.4 & 0.11 & 0.105 \\
\hline Average daily feed intake, $g$ & 80.6 & 81.9 & 79.9 & 83.9 & 1.24 & 0.183 \\
\hline FCR & 1.31 & 1.33 & 1.35 & 1.33 & 0.020 & 0.723 \\
\hline \multicolumn{7}{|l|}{ Day 0-21 } \\
\hline Weight at day $21, \mathrm{~g}$ & $934.1^{\mathrm{ab}}$ & $941.6^{\mathrm{ab}}$ & $906.9^{b}$ & $961.7^{\mathrm{a}}$ & 1.38 & 0.047 \\
\hline Average daily gain, $\mathrm{g}$ & $42.5^{\mathrm{ab}}$ & $42.8^{\mathrm{ab}}$ & $41.3^{\mathrm{b}}$ & $43.9^{\mathrm{a}}$ & 0.50 & 0.036 \\
\hline Average daily feed intake, $g$ & 56.5 & 56.5 & 57.0 & 58.6 & 0.89 & 0.356 \\
\hline FCR & 1.33 & 1.32 & 1.38 & 1.33 & 0.024 & 0.225 \\
\hline Energy conversion rate (MJ/kg BWG) & 16.04 & 15.88 & 16.60 & 16.06 & -- & -- \\
\hline
\end{tabular}

${ }^{1}$ Data are means of twelve observations per treatment. 
669 Figure 1. Hydrolysis of (A) triglycerides and accumulation of (B) free fatty acids, (C) 670 diglycerides and (D) monoglycerides during the in vitro hydrolysis of palm oil (solid line), 671 palm oil with soybean lecithin (dotted line) and palm oil with soybean lysolecithin (dashed 672 line). The experimental treatments were carried out in triplicate. The mean concentrations of 673 the lipids $(\mathrm{mg} / \mathrm{ml})$ are given over time $(\mathrm{min})$, with error bars indicating the standard error 674 values. Statistical analysis of the treatments is performed based on apparent rate constants (see 675 Table 1). For enzyme kinetic comparison, apparent rate constants are used. (Experiment 1).

677 Figure 2. Absorption of monoglycerides (white bars) and free fatty acids (grey bars) generated 678 during in vitro hydrolysis of palm oil, palm oil with soybean lecithin and palm oil with soybean 679 lysolecithin by differentiated Caco-2 monolayers and expressed as percentage of applied 680 monoglycerides end free fatty acids. Data are means of three or more observations per 681 treatment, with error bars indicating the standard error values. (Experiment 1). 